NBER WORKING PAPER SERIES

\title{
EFFECT OF EMPLOYER ACCESS TO CRIMINAL HISTORY DATA ON THE LABOR MARKET OUTCOMES OF EX-OFFENDERS AND NON-OFFENDERS
}

\author{
Keith Finlay \\ Working Paper 13935 \\ http://www.nber.org/papers/w13935 \\ NATIONAL BUREAU OF ECONOMIC RESEARCH \\ 1050 Massachusetts Avenue \\ Cambridge, MA 02138 \\ April 2008
}

I am grateful to David Neumark and David Autor for extensive comments. I have also benefitted from the suggestions of Marigee Bacolod, Francesca Mazzolari, Bob Michael, Anne Polivka, and seminar participants at the 2007 Society of Labor Economists Meetings, the NBER Labor Market Intermediation Conference, the 2007 Southern Economics Association Meetings, the Public Policy Institute of California, and the NLSY97 Tenth Anniversary Conference. The views expressed herein are those of the author(s) and do not necessarily reflect the views of the National Bureau of Economic Research.

NBER working papers are circulated for discussion and comment purposes. They have not been peerreviewed or been subject to the review by the NBER Board of Directors that accompanies official NBER publications.

(C) 2008 by Keith Finlay. All rights reserved. Short sections of text, not to exceed two paragraphs, may be quoted without explicit permission provided that full credit, including $\odot$ notice, is given to the source. 
Effect of Employer Access to Criminal History Data on the Labor Market Outcomes of Ex-Offenders and Non-Offenders

Keith Finlay

NBER Working Paper No. 13935

April 2008, Revised September 2008

JEL No. D82,D83,J71,J78,K42

\begin{abstract}
Since 1997, states have begun to make criminal history records publicly available over the Internet. This paper exploits this previously unexamined variation to identify the effect of expanded employer access to criminal history data on the labor market outcomes of ex-offenders and non-offenders. Employers express a strong aversion to hiring ex-offenders, but there is likely asymmetric information about criminal records. Wider availability of criminal history records should adversely affect the labor market outcomes of ex-offenders. A model of statistical discrimination also predicts that non-offenders from groups with high rates of criminal offense should have improved labor market outcomes when criminal history records become more accessible. This paper tests these hypotheses with criminal and labor market histories from the 1997 cohort of the National Longitudinal Survey of Youth. I find evidence that labor market outcomes are worse for ex-offenders once state criminal history records become available over the Internet. Non-offenders from highly offending groups do not appear, however, to have significantly better labor market outcomes. The sign of the non-offenders estimates are consistent with the predictions of the statistical discrimination model, but the estimates are not significantly different from zero. These estimates may be confounded by a short sample period and ongoing human capital investments, but the research design provides a unique setting for testing theories of statistical discrimination.
\end{abstract}

\author{
Keith Finlay \\ Department of Economics \\ 206 Tilton Hall \\ Tulane University \\ New Orleans, LA 70118 \\ kfinlay@tulane.edu
}




\section{Introduction}

At the end of 2001, an estimated 5.6 million adults had served time in state or federal prison, including 4.3 million former prisoners and 1.3 million adults in prison. Each year, more than half a million state and federal prisoners are released from correctional institutions and may attempt to re-enter the civilian labor force (Harrison and Beck 2006). As these ex-offenders seek employment, they face employers averse to hiring applicants with criminal records. Until recently, it has been difficult for hiring officials to verify an applicant's criminal history. Since 1997, states have begun to make criminal history records publicly available over the Internet, which has lowered the cost and increased the scope of the criminal background checks that can be conducted in those states. This paper exploits this previously unexamined variation to measure the effect of expanded access to criminal history data on the labor market outcomes of ex-offenders and non-offenders. Since an employer's decision to conduct criminal background checks is likely a function of his applicant pool, using policy variation in record openness should provide estimates closer to the direct effect of greater information available to employers during hiring.

Employers are apprehensive to hire ex-offenders, so opening criminal history records is expected to worsen their labor market opportunities. But economic theory predicts effects for nonoffenders as well. Employers have imperfect information about the criminal records of applicants, so rational employers may use observable correlates of criminality as proxies for criminality and statistically discriminate against groups with high rates of criminal activity or incarceration. In the absence of open records, non-offenders from groups with high incarceration rates would be adversely affected. When accurate criminal history records become easier to obtain, the labor market outcomes of these non-offenders should improve as employers can determine with greater certainty whether applicants have criminal records.

This paper tests these hypotheses using detailed criminal and labor market histories from the 1997 cohort of the National Longitudinal Survey of Youth (NLSY97). The criminal history variables in this survey allow me to distinguish ex-offenders from non-offenders. I also use the criminal histories to model employer perceptions of criminality assuming that they are based on rational expectations of incarceration probabilities. I find evidence that labor market outcomes are worse for ex-offenders once state criminal history records become available over the Internet, 
which demonstrates that employers have imperfect information about criminal histories. Nonoffenders from highly offending groups do not appear, however, to have significantly better labor market outcomes. The sign of the non-offenders estimates are consistent with the predictions of the statistical discrimination model, but the estimates are not significantly different from zero. It is important to note that these estimates may be confounded by a short sample period and ongoing human capital investments.

This study makes two important contributions to the empirical literature on the labor market effects of employer use of pre-employment screening technologies: it exploits an exogenous change in the employer's information set to identify the effect of that information and it uses observed criminal history data to distinguish effects for less desirable applicants (offenders) from more desirable applicants (non-offenders). The research design makes use of technological changes in the amount of criminal history data available to employers. This strategy contrasts with research that uses variation in employer decisions to conduct criminal background checks, since these decisions are likely endogenous to the composition of applicant pools. For example, Holzer, Raphael, and Stoll (2006) use establishment data on employer use of criminal background checks and preferences toward hiring ex-offenders. They find evidence that employers who are averse to hiring ex-offenders are relatively more likely to hire black men if they conduct criminal background checks. Since black men are more likely to be incarcerated than white men, they argue that this is evidence of statistical discrimination in the absence of background checks. The authors control for some observable characteristics of the applicant pool, but the employers that choose to use criminal background checks do so because of the potential of hiring an ex-offender, which generally is a quality unobservable to researchers using firm-level data. In order to get estimates that are closer to the causal effect of criminal background checks, my analysis identifies the effect of employer access to criminal records using variation that is unrelated to the proportion of ex-offenders in the affected labor markets or the hiring preferences of employers.

The research design used in this paper is similar to one used by Autor and Scarborough (2008) to study the diffusion of pre-employment personality tests at a national retail chain. They find that the relative hiring of blacks did not fall after the introduction of the tests, despite the fact that blacks in general perform worse on the tests, and they suggest that managers were effectively statistically discriminating before the tests. Both that paper and this paper use technological changes 
in the employer's information set to study how more information affects groups who do poorly on the pre-employment screen (e.g., personality tests or criminal background checks). This paper also builds upon this approach by exploiting longitudinal criminal history data to distinguish exoffenders from non-offenders (or more generally, undesirable from desirable applicants). Using this information, I explicitly model employer perceptions of the criminality of potential employees using characteristics observable to both the employer and the researcher. These data allow me to estimate separate effects of expanded access to criminal histories for ex-offenders and nonoffenders, which allows for a unique test for statistical discrimination.

In addition to providing an empirical test of statistical discrimination, the results of this paper are important for understanding the transition of ex-offenders back into the legitimate labor force. As the flow of released prisoners increases over the next ten years, the issue of re-entry into the legitimate labor market will force policy makers to consider the unintended consequences of open criminal history records. Legitimate employment is a strong predictor of criminal desistence (Sampson and Laub 1993, Needels 1996, Uggen 2000), so expanded use of criminal background checks has the potential to increase recidivism and the long-term fiscal costs of criminal punishment. But there may also be some beneficiaries from open records. All else equal, individuals who do not have criminal records but come from highly offending groups stand to benefit from a more transparent criminal records system.

The paper is structured as follows. First, I outline recent changes in the availability of criminal background data and how I use these changes for this study. Then, I consider how more open criminal history records may affect ex-offenders and non-offenders, review the literature related to the labor market outcomes of ex-offenders, and review some literature on the labor market effects of pre-employment screening. Next, I describe the individual-level data. Then, I discuss the empirical strategy, regression results, and conclusions.

\section{Expanded availability of criminal history data}

A criminal history record positively identifies an individual and describes that person's arrests and subsequent dispositions relating to a criminal event. Until recently, they been used primarily for law enforcement purposes. Criminal history records have been legally available to the public 
since the 1976 case Paul v. Davis, in which the Supreme Court ruled that the publication of official acts, including arrest, conviction, and incarceration records, were not protected by privacy rights. ${ }^{1}$ Widespread use of criminal background checks as a pre-employment screen is a relatively recent phenomenon that stems from expanded legal availability and technical improvements that have made records more accessible.

Employer demand for criminal background checks is driven by their aversion to hiring applicants with criminal records. Criminal offenders may have fewer skills or be more likely to commit crime at the workplace, which can expose employers to negligent hiring lawsuits. ${ }^{2}$ In a 2001 survey of employers, more than 60\% would "probably not" or "definitely not" hire an exoffender (Holzer et al. 2006). The US Equal Employment Opportunity Commission (1987a, 1987b) has declared that employers may violate Title VII of the Civil Rights Act of 1964 if they broadly deny employment to applicants with criminal records, but that employers can ban applicants who have committed particular offenses if employers demonstrate these offenses are directly related to job functions. Some states have more severe restrictions, but there is little evidence of active enforcement.

Given the risks of hiring ex-offenders and the relatively low cost of conducting criminal background checks, human resource practitioners now recommend conducting checks on all hires (Andler and Herbst 2003, Rosen 2006). Evidence from employer surveys shows a large increase in the last two decades in the use of criminal background checks during the hiring process. Holzer, Raphael, and Stoll (2007) report responses from surveys of Los Angeles employers in 1992-1994 and 2001. In the 1992-1994 sample, 32\% of employers reported that they always conducted criminal background checks. In the 2001 sample, 46\% said they always conducted criminal background checks. In 2004, the Society for Human Resource Management surveyed its members about preemployment screening practices. In this national sample, $68 \%$ responded that they always conduct criminal background checks. These samples are not directly comparable, but they suggest

\footnotetext{
${ }^{1}$ Paul v. Davis, 424 US 693 (1976).

${ }^{2}$ Negligent hiring can occur when an employee causes injury to a customer or co-worker, and the employer failed to take reasonable action in hiring that could have prevented the injury. A 2004 survey of human resource managers found that $3 \%$ of their firms had been accused of negligent hiring in the three years before the survey (Burke 2005). Although the incidence of negligent hiring suits can be small, the potential monetary costs can be substantial. Wider availability of criminal background checks may be an important cause of increased attention to negligent hiring, since it lowers the cost of "reasonable" due diligence. See Odewahn and Webb (1989), Johnson and Indvik (1994), and Connerley, Arvey, and Bernardy (2001) for a background on negligent hiring.
} 
that employer use of criminal background checks has increased substantially over time.

Employers who conduct criminal background checks must decide who to have conduct the search and over what jurisdictions to search. ${ }^{3}$ Private providers of background checks are plentiful, but the accuracy of their searches is not guaranteed to be any better than if an employer conducts the check on his own (Bushway et al. 2007). In reality, employers have no access to a national criminal background check. The Federal Bureau of Investigation maintains the only national repository of criminal records, known as the National Crime Information Center (NCIC), but it is not accessible by the general public. In lieu of a national search, most employers settle for a localized search of criminal records, which have historically been conducted by couriers at local courthouses. Employers seeking a wider search of criminal history data can use state databases that aggregate local and state arrest, conviction, and incarceration records.

Until the mid-1990s, there were few state-level resources for criminal background checks, but state-level databases are increasingly the most comprehensive sources of criminal history data. ${ }^{4}$ Automation of records by the states was facilitated by the National Criminal History Improvement Program, which was mandated by the Brady Handgun Violence Prevention Act of $1993 .{ }^{5}$ The Act imposed a five-day waiting period for firearm purchases and required that prospective gun owners clear background checks during that waiting period. The Act also stipulated that within five years of its effective date such checks should be performed instantaneously through a national criminal background check system maintained by the Department of Justice (which became the FBI's NCIC system), and allocated funds for states to automate their records. Since 1995, states have received approximately $\$ 400$ million to improve data quality and speed the time between a criminal history event and when it is entered into a state-level database (Brien 2005). As a result of the Brady Act, states began to have the technical capability to make criminal history records more accessible. In the late 1990s, some states began to make these records available over the Internet. Internet-based criminal background checks are significantly more convenient than any other method and state-level aggregation increases the geographic scope of background checks, so provision of criminal history records over the Internet is one of the most significant changes

\footnotetext{
${ }^{3}$ See Rosen (2006) and Hinton (2004) for thorough discussions of criminal background check sources and reliability.

${ }^{4}$ From 1993 to 2001, the number of individuals in state criminal record databases increased from 47 million to 64 million (SEARCH 1994, Brien 2005). Over the same period, the proportion of all criminal history records that were automated increased from $79 \%$ to $89 \%$ (SEARCH 1994, Brien 2005).

${ }^{5}$ Public Law 103-159, Title I, 30 November 1993, 107 Statute 1536.
} 
in the accessibility of records since the Supreme Court declared them public records in 1976. For these reasons, I use the provision of records over the Internet as the policy variation to identify the effect of record openness on labor market outcomes of ex-offenders and non-offenders.

A state is classified as having open records if, in a given year, it provides online access to the criminal histories of individuals released from its prisons. I collected this panel of policy data directly from state departments of correction or state police agencies, starting with a cross section of policies reported by the Legal Action Center (2004). Officials were asked when their state first provided criminal history records of released prisoners over the Internet. These websites allow any member of the public to search for ex-offenders who served their time in that state's prison system. In general, this will not be all prisoners, but rather prisoners who were sentenced to a year or more of prison time in local or state but not in federal courts. Although this is a subset of all prisoners, it is the majority of the incarcerated population. The sites provide personal information—such as name and aliases, birthdate, physical characteristics, and race-that allow a searcher to positively identify an ex-offender. The searches also detail the offenses for which time was served, lengths of the sentences, and release dates for each offense. Some systems only identify current offenders, but this information is not useful to employers, so these states are not coded as having open records.

Figure 1 is a map of the US showing the states that provide access to criminal records over the Internet, and the first year that information was available online. Between 1997 and 2004, 16 states began to make their criminal records available over the Internet. ${ }^{6}$ The map shows that the expansion of access to criminal history records at the state level has been geographically and temporarily disperse-an important feature of my identification strategy. To account for timeinvariant unobservable differences across states that adopt open records versus states that do not adopt open records, all empirical models include state fixed effects. All models include year fixed effects to account for the overall relative employment trends of ex-offenders. Then, the effects of opening criminal records are identified if there are no contemporaneous trends in labor market outcomes for ex-offenders relative to non-offenders in states that open records versus states that

\footnotetext{
${ }^{6}$ Florida was the first state to open records in this way in 1997. It was followed by New York and Washington state in 1998; Michigan and South Carolina in 1999; Georgia, Indiana, New Mexico, and Wisconsin in 2000; Kansas, Nebraska, and North Carolina in 2001; Montana and Oklahoma in 2002; and Vermont in 2003.
} 
do not. If these conditions hold, this research design will yield estimates of the causal effects of greater information for employers about the criminal histories of their applicants.

One threat to identification of a causal effect is if states choose to make records available online based on legislative decisions related to employer preferences toward hiring ex-offenders. Fortunately, state adoption of Internet-based records searches was primarily a function of administrative decisions and the removal of technological hurdles. Of the sixteen states distributing criminal history records to the public in my sample, eight states responded to a survey by SEARCH (2006) of their governments' criminal records practices. ${ }^{7}$ Of these, seven states were providing records over the Internet because of an administrative decision that relied on some pre-existing statute. Only one state (Oklahoma) was opening records by a direct order of legislation. This evidence suggests that the timing of record openness was not primarily a result of specific legislation. In another survey by SEARCH (2001), state officials responsible for criminal history records emphasized the importance of technical issues in determining when records went online. The statements of these officials support the argument that the limiting factor in the public provision of criminal history data over the Internet was technology rather than political preferences. ${ }^{8}$ Therefore, the temporal variation in introduction of open records, combined with state and year fixed effects, should allow for the identification of the causal effect of expanded access to criminal records on the labor market outcomes of ex-offenders and non-offenders.

\footnotetext{
${ }^{7} \mathrm{SEARCH}$, the National Consortium for Justice Information and Statistics, has conducted surveys of criminal records systems on behalf of the Bureau of Justice Statistics.

${ }^{8}$ For example, Dave Sim of the Kansas Bureau of Investigation alludes to a learning process in administrative agencies with respect to providing criminal history data over the Internet:

Kansas maintains a prototype system that provides select non-criminal justice entities with Internet access to criminal history record information. The State will expand access to all users when it migrates from the prototype to its final design later in 2001. The system was designed primarily for criminal justice agencies but Kansas provided limited non-criminal justice access as it gained experience with Internet operations. (SEARCH 2001)

In the same survey, Ruth Lunn of the Maine State Police reported that Maine had not even begun the automation process necessary to provide records over the Internet (SEARCH 2001). Her responses do not mention statute as the limiting factor in providing records, but rather the technological issues. David Dishong of the Nebraska State Patrol also suggested that the timing of public access to records over the Internet was a function of "programming and procedural issues" (SEARCH 2001).
} 


\section{Literature review and hypotheses}

\section{Labor market effects of incarceration}

This paper addresses the effects of changes in the availability of criminal history records. Since employers use these records to identify ex-offenders, it would be useful to first discuss the literature that examines the labor market effects of incarceration. Determining the effect of conviction or incarceration on employment and wages is nontrivial since criminal offenders may have unobservable qualities that affect both their labor market outcomes and their propensities to commit crime. Researchers have employed a variety of methods to identify unbiased estimates of the effect of incarceration on employment and wages. Grogger (1995) compares the labor market outcomes of offenders before and after periods of incarceration. Kling (2006) uses variation in judge sentencing to instrument for individual sentence length. Another strategy is to use more homogeneous samples, such as those that will ever be convicted or incarcerated, an approach used by Grogger (1995), Western (2002), and Kling (2006). This literature tends to find small negative, statistically significant effects of incarceration on wages and employment without sample restrictions. Once less heterogeneous samples or fixed effects strategies are used, estimates attenuate and commonly become insignificant. ${ }^{9}$ Following this literature, some of the specifications in this paper use individual fixed effects to account for unobservable heterogeneity. My research also complements this literature by exploring how employers learn about the criminal records of potential employees.

\section{Labor market effects of criminal background checks}

Since employers have a strong aversion to hiring ex-offenders and since criminal history records have recently become more accessible, it is not surprising that the use of criminal background checks has increased at the same time the number of ex-offenders has increased. Given the large racial differential in incarceration rates, the small literature on the labor market effects of criminal background checks has focused on how greater use of or access to criminal records affects the relative hiring or employment rates of black men. While the theory of statistical discrimination predicts that open records will worsen the outcomes of black ex-offenders and improve the

\footnotetext{
${ }^{9}$ Almost all prisoners are male, so most studies of the labor market effects of incarceration use only samples of men. But in a recent study of women incarcerated in Illinois, Cho and LaLonde (2005) find some positive effects of incarceration on earnings.
} 
outcomes of black non-offenders, the theory is ambiguous about the net effect for blacks relative to whites. None of the existing studies of criminal history records rely on data that distinguishes ex-offenders from non-offenders, so the authors focus on the net effect for blacks relative to whites.

Holzer et al. (2006) use establishment data on employer use of criminal background checks and preferences toward hiring ex-offenders. They argue that firms that prefer not to hire ex-offenders will be more likely to hire black applicants if they also conduct background checks. Employers who state an aversion to hiring ex-offenders are more sensitive to asymmetric information with respect to the criminal records of job candidates. Therefore, these employers have a stronger incentive to statistically discriminate, and so the relative hiring of blacks should be more positively affected once these firms conduct criminal background checks. The authors find evidence that supports this hypothesis and indicates that employers do statistically discriminate. But employers who conduct criminal background checks may also have applicant pools with a higher proportion of applicants who are black or have criminal records. Some of the estimated parameters of interest are not significantly different from zero once the authors control for the composition of each firm's applicant pool. Nonetheless, the study is an important look at the effects of criminal background checks and the results provide some evidence that opening records may lead to net benefits for individuals from highly offending groups.

In the first attempt to examine the availability of records across states, Bushway (1996) finds that the weekly earnings of young, black men with a high school degree were higher in states that had more of their criminal history records automated-a measure he argues can serve as a proxy for record accessibility. In other work, Bushway (2004) uses a composite record openness score generated by the Legal Action Center (2004). He finds that the ratio of black to white wages was higher and the ratio of black to white employment probabilities was lower in states that had higher openness scores, although neither estimate is significant. The estimated effect on wages is consistent with large drops in employment if it is primarily low-skilled black men that are dropping out of the labor market. While Bushway is the first to use state variation to measure the labor market effects of criminal background checks, his work is cross-sectional, so it does not control for unobserved differences in labor markets across states particular to black men that are correlated with criminal records automation or accessibility. My research design builds upon Bushway's work by using a panel of state policies regarding criminal history records, which should better 
isolate the direct effect of employer access to records on labor market outcomes.

In a very different research design, Pager (2003) conducted an audit study of the effect of criminal records. In the study, four male, college-educated auditors each applied to low-skill job listings in Milwaukee. One pair was black, one pair was white, and one of each pair identified himself as having a criminal record. The callback rate for ex-offenders was less than half of the callback rate for non-offenders. Pager also finds that the callback rate for the black, ex-offender applicants was lower than the callback rate for the white, ex-offender applicants, controlling for a lower overall callback rate for all black applicants, although the interaction estimate is not significantly different from zero. Pager's results suggest that the labor market effects of incarceration are tied to the effects of race in the labor market. The results also highlight the difficulty that ex-offenders have in gaining employment after release.

While the above papers have examined the net effect of access to criminal histories on blacks relative to whites, economic theory predicts more nuanced effects for non-offenders and ex-offenders that may result from statistical discrimination by employers. If employers are averse to hiring ex-offenders, then they have an incentive to use observable correlates of criminality or incarceration as proxies for those qualities. Using these proxies, employers can classify individuals as coming from groups with low rates of incarceration (or low perceived criminality) or high rates of incarceration (high perceived criminality). In the absence of open records, one would observe an averaging of the labor market outcomes for individuals within either group. For example, black men who are high school dropouts have very high incarceration rates. If employers statistically discriminate, then the outcomes for black non-offenders that have not completed high school will be relatively worse than they would have been without statistical discrimination, but ex-offenders from that group will have relatively better outcomes. Similarly, white ex-offenders should benefit from statistical discrimination because they come from a group with relatively low rates of incarceration.

Now suppose that criminal history records become publicly available. If employers can directly observe criminal history records, they no longer need to rely on statistical discrimination. This will cause a separation in the labor market outcomes of ex-offenders and non-offenders within highly offending groups. Specifically, ex-offenders should do worse and non-offenders should have improved labor market outcomes. Figure 2 illustrates the main features of the model. 
Each panel shows a plot of labor market outcomes (hiring odds or wages) against an index of perceived criminality. Perceived criminality is a index created by the employer using observable proxy variables as a substitute for observed criminality. Panel A shows the hiring policy when criminal records are not available to employers. The dotted line shows that labor market outcomes are decreasing in perceived criminality. Panel B shows the hiring policy when criminal records are available to employers. In this case, there would be a bifurcation from the hiring policy under closed records. Now that employers can distinguish offenders from non-offenders, the labor market outcomes of non-offenders with high perceived criminality improve. Also note that offenders with low perceived criminality suffer a greater decline in labor market outcomes relative to other offenders.

A simple empirical model can capture the main characteristics of the model shown in Figure 2 For a relevant labor market outcome $Y$, one could estimate the following regression:

$$
\begin{aligned}
Y= & \beta_{0}+\beta_{1} P C+\beta_{2} \text { Access } \cdot \text { Inc }+\beta_{3} P C \cdot \text { Access } \\
& +\beta_{4} P C \cdot \text { Access } \cdot \text { Inc }+\beta_{5} P C \cdot \text { Inc }+\beta_{6} \text { Access }+\beta_{7} \text { Inc }+\varepsilon,
\end{aligned}
$$

where Access indicates if employers have access to criminal history records, Inc is a dummy for an individual's own criminal record, $P C$ is the employer's perception of the individual's criminality, and $\varepsilon$ is an error term. Note that this model could apply generally to any situation in which some employers have technical access to the criminal history data of their applicants and some do not (and this accessibility is not a function of an employer's decision). For the moment, I will abstract away from a more complete model that includes the individual controls and fixed effects required to identify the effects of open records in my institutional context.

This model can be used to test the two primary hypotheses generated by the model of statistical discrimination. First, the model predicts that the main effect of true criminality should become more negative when employers can access criminal history records. This effect is captured by the coefficient on the interaction of Inc and Access, so it can be tested with the alternative hypothesis $\beta_{2}<0$ and null hypothesis $\beta_{2} \geq 0$. Second, the model predicts that non-offenders with high perceived criminality should have improved labor market outcomes if potential employers can verify that they are non-offenders (i.e., when criminal history records are publicly available). 
This hypothesis mirrors one in which ex-offenders with high perceived criminality have relatively worse outcomes from similar non-offenders once records are open. This can be tested with the alternative hypothesis $\beta_{3}<0$ and null hypothesis $\beta_{3} \geq 0$. Note that both of these hypotheses test relative and not absolute effects of employer access to criminal history data.

This statistical discrimination framework will guide the empirical approach that follows. First, I discuss the individual data on criminal and labor market histories that will be used to estimate the model suggested above.

\section{Data}

This paper uses the criminal and labor market histories from the 1997 cohort of the National Longitudinal Survey of Youth (NLSY97). The NLSY97 includes a nationally representative sample of all youths aged 12-16 years by the end of 1996, and an over-sample of black and Hispanic youths meeting the same age restriction. Currently, the NLSY97 has released eight rounds of data, covering interviews from 1997 through 2004. The NLSY97 is an excellent sample for this project because it has information about both the criminal activity of respondents and their labor market outcomes. This is a rare quality for a nationally representative survey, and the NLSY97 is especially useful because the sample period coincides with the introduction of Internet sites for accessing criminal history records. The criminal records policies discussed above are matched with individual respondents using the state geocodes available in the private-release version of the NLSY97. There are a few drawbacks of using the NLSY97 for this research. This is a very young sample when the first states make their records available online. While young people are the most likely to be incarcerated, many of the survey respondents are still completing their schooling at or near the end of the sample period. This limits the extent to which the labor market outcomes of NLSY97 respondents can reasonably be affected by changes in criminal records openness. Table 1 shows the number of NLSY97 respondents aged more than 18 years, by age and survey year. It shows the small range of adult ages available in Round 8 of the NLSY97, the most recent survey year. The oldest survey participants have aged 25 years, but few individuals have reached this age in the sample period. 
The sample I use in regression analysis consists of men and women aged at least 18 years, covering survey years 1997-2004. Because of the particular importance of clearly identifying race and ethnicity for this analysis, the sample is further restricted to respondents who are either nonHispanic white, non-Hispanic black, or Hispanic. I use both the representative sample and the minority oversample with sampling weights. ${ }^{10}$ Table 2 shows how the sample restrictions affect the number of individuals and panel observations. Up to Round 8, the NLSY97 is composed of 64,336 completed interviews from 8,984 survey participants. With the age, race, and ethnicity restrictions, the analytic sample is reduced to 37,114 observations on 8,332 respondents. ${ }^{11}$ In regressions of labor market outcomes, I also exclude individuals who are incarcerated at the time of their interviews since those incarcerations might mechanically determine employment and earnings in a way that is unrelated to employer decisions. This restriction leaves 36,687 observations from 8,304 individuals. In regressions that exploit within-individual variation in labor market outcomes, identification effectively comes from the 7,945 individuals who have at least two interviews (36,328 observations).

I use three labor market outcomes as dependent variables: employment status, the natural logarithm of hourly wage, and the natural logarithm of annual earnings. Employment status is equal to one if the respondent was employed at the date of the interview. Hourly wage is the maximum of the NLSY-created hourly wage variables for each job held since the last interview. The earnings variable is the total income from wages and salary in the calendar year before the interview. ${ }^{12}$ Employment status is observed for all respondents (36,687 observations), while there are only 30,145 positive observations for wages and only 27,137 positive observations for annual earnings.

The NLSY97 also has extensive information on interactions with the criminal justice system. ${ }^{13}$ Incarceration information comes from two types of questions. First, if the interview was conducted at a jail or the respondent classified their dwelling as a correctional institution, this was noted. Second, an iterative round of questions addressed any arrests and whether they led to con-

\footnotetext{
${ }^{10}$ Custom sampling weights for NLSY97 respondents in any survey year come from http://www.nlsinfo.org/ web-investigator/custom_weights.php

${ }^{i 1}$ In addition, two observations are dropped because they have sampling weights equal to zero.

${ }^{12}$ Wages and earnings are inflated to 2005 dollars using the All-Urban series of the Consumer Price Index.

${ }^{13}$ The criminal history data in the NLSY97 is used by Lochner (2007) to study how young people update arrest probabilities and by Hjalmarsson (2008) to study the effect of conviction and incarceration on high school completion. These papers focus on criminal justice interactions as a minor, while this paper focuses on adult interactions.
} 
viction or incarceration. I created indicator variables for whether the respondent was incarcerated at the time of the interview or since the date of the last interview. Since this research is about criminal history records that are limited to adult offenses, I also constructed incarceration indicators that are restricted to adult offenses. ${ }^{14}$ Finally, a variable was created to indicate whether the respondent had ever been incarcerated as an adult by the date of the current interview. ${ }^{15}$

I also include a number of other variables as controls. To control for labor market experience, I use the years of accumulated labor market experience from age 13. Education controls include accumulated years of school attended since age 13 and a set of dummies for highest degree received as of June 30 of the survey year (namely, whether the individual has a general equivalency diploma (GED), a high school diploma, an associates degree, or a bachelors or postgraduate degree). To account for macroeconomic conditions, the state-level unemployment rate is also included as a control. In regressions without individual fixed effects, the Armed Services Vocational Aptitude Battery (ASVAB) test score and race, ethnicity, and gender indicators serve as controls.

\section{Descriptive statistics}

Table 3 shows selected descriptive statistics for labor market outcomes, incarceration, and other covariates from the last survey round in which NLSY97 respondents participated. The employment rate at the end of the sample is $72 \%$. The average wage is $\$ 12.15$ and the average annual earnings are about $\$ 10,400$. Four percent of the sample has been incarcerated as an adult. The average age in the last reported interview is almost 22 years. Respondents report average work experience of about 7 years, which includes work experience as a minor. Average completed schooling is almost 13 years, although $30 \%$ of the sample is still enrolled in school at the end of the sample.

Table 3 also details how ex-offenders and non-offenders differ across observable characteristics. Ex-offenders are significantly less likely than non-offenders to be employed (59\% versus $72 \%$, respectively). Despite the employment differential, the hourly wages of ex-offenders are not significantly different from the hourly wages of non-offenders (although the mean is lower for ex-

\footnotetext{
${ }^{14}$ It is difficult to determine in which state each respondent experienced his conviction or incarceration, so I cannot make a clean determination if an individual's records are definitely available to employers in his state-of-residence if he has moved across states. Luckily, there are relatively few interstate moves.

${ }^{15}$ Studies of post-incarceration employment have found no significant effect of longer sentences on labor market outcomes (Needels 1996, Kling 2006), so I focus on the binomial characterization of past incarceration.
} 
offenders, the difference is not significantly different from zero). This might be explained by the higher rate of school enrollment of non-offenders (31\% of non-offenders are enrolled, but only $8 \%$ of ex-offenders are enrolled). Ex-offenders also have fewer years of completed schooling and less labor market experience. Finally, the table shows that the proportion of individuals that live in states that provide criminal history data over the Internet is qualitatively similar across offender status. In the analytic sample, 39\% of respondents who have been incarcerated live in such a state, while $37 \%$ of the other respondents live in open-records states.

Table 4 shows the age profiles for adult incarceration rates of NLSY97 respondents, broken down by gender, race, and ethnicity. ${ }^{16}$ The differences in incarceration probabilities across both gender and race are stark. Black males are about four times as likely as white males to be incarcerated at any particular age. Hispanic males are somewhat more likely to be incarcerated than white males, but not to the same extent as blacks. For example, of males aged 22 years, $8.2 \%$ of black respondents were incarcerated, while $3.0 \%$ of Hispanic males and $2.3 \%$ of white males were incarcerated. Males of any race are significantly more likely to be incarcerated than their female counterparts. These incarceration rates are qualitatively similar for men of these ages from other data sources, although the rates are somewhat lower. Using data from the 2000 Census, Raphael (2006) reports that $11 \%$ of black men aged $18-25$ years and $2 \%$ of white men aged 18-25 years were incarcerated. This suggests that incarceration is somewhat underreported in the NLSY97. ${ }^{17}$

Figure 3 and Table 5 show the cumulative age profiles for adult-incarceration rates of NLSY97 respondents, broken down by gender, race, and ethnicity. The gender and racial patterns of the age-specific incarceration probabilities are also seen in the cumulative rates. (Note that the cumulative rates are not monotonic because of the age structure of the respondents and survey nonresponse and attrition.) By age 24, almost 19\% of black men have been incarcerated as an adult, while about $8 \%$ of white men and about $12 \%$ of Hispanic men have been incarcerated as an adult. These cumulative rates are qualitatively consistent with published rates from the Bureau of Justice Statistics (Bonczar and Beck 1997, Bonczar 2003).

\footnotetext{
${ }^{16}$ Age 25 is excluded because of small sample sizes.

${ }^{17}$ Survey respondents are known to underreport criminal activity, and these underreports tend to be larger for blacks (Hindelang, Hirschi, and Weis 1981, Viscusi 1986, Abe 2001).
} 


\section{Regression results}

This section presents regression results of the labor market effects of more open criminal history records. First, I focus on the effects for ex-offenders. Then, I examine how more open criminal history records affect the labor market outcomes of both ex-offenders and non-offenders from highly offending groups.

\section{Access to criminal history data and the employment effects of incarceration}

There are a number of reasons to believe that employer access to criminal history data may influence the labor market effects of incarceration. First, employers in states that do not have open criminal records may have trouble distinguishing ex-offenders from non-offenders, so adoption of open records should adversely affect the labor market outcomes of ex-offenders relative to nonoffenders. Second, if employers are risk averse, the negative labor market effects of incarceration may last longer under an open criminal records policy. Moreover, even higher productivity exoffenders may have longer lasting employment problems if employer risk aversion prevents them from being hired in the first place. Finally, if employers also underestimate the degree of criminality among applicants, then greater employer access to criminal history records may also harm offenders on average without necessarily benefitting non-offenders.

The effect of wider availability of criminal history records on the labor market outcomes of ex-offenders is estimated in the following regression:

$$
Y_{i s t}=\delta_{0}+\mathbf{X}_{i s t} \delta_{1}+\delta_{2} I_{n c_{i t}}+\delta_{3} \text { Access }_{s t}+\delta_{4} \text { Access }_{s t} \text { Inc }_{i t}+\gamma_{s}+\gamma_{t}+\nu_{i s t},
$$

where $Y_{i s t}$ is a relevant labor market outcome of individual $i$ living in state $s$ in year $t$. Inc $c_{i t}$ is equal to one if individual $i$ has been incarcerated as an adult by year $t$, and Access st is equal to one if state $s$ has an Internet site in year $t$ on which the public can search for the incarceration records of ex-offenders. State fixed effects $\gamma_{s}$ account for any time-invariant differences across states that adopt open records and states that do not. Year effects $\gamma_{s}$ account for any secular changes in labor market outcomes. $\mathbf{X}$ is the vector of individual controls discussed above, and $\nu$ is the error term. In order to meaningfully interpret the coefficient on Access, each continuous covariate in 
this vector is centered by its mean from each regression's respective sample. The parameter of interest $\delta_{4}$ is the difference in the employment outcomes between ex-offenders in states with more open records versus ex-offenders in states with more closed records.

Table 6 shows the estimates from Equation 2 for each labor market outcome using two identification strategies. In the odd-numbered columns, the parameters are identified off of the state and time variation in the introduction of the provision of criminal history records over the Internet. These specifications treat the data as repeated cross-sections and use state and year fixed effects for identification. In the even-numbered columns, the parameters are identified off of changes in both offender status and perceived criminality, in addition to the temporal and spatial variation in the introduction of open records. These specifications exploit the panel structure of the NLSY97 and include individual fixed effects and year effects, but exclude the state effects and time-invariant controls. ${ }^{18}$

Employment status is the dependent variable in Columns 1 and 2. In Columns 3 and 4, the dependent variable is the log of hourly wages. And in Columns 5 and 6, the dependent variable is annual earnings. For each identification strategy, the table shows results with and without the open records variables included. I first replicate the basic results of how incarceration affects labor market outcomes. While a number of papers have considered these effects using other data, I know of no other papers that estimate labor market effects of incarceration using the more recent NLSY97. By first estimating the incarceration effects with this new data, we can interpret the estimated effects of background checks in the context of previous estimates of incarceration effects. This exercise will also verify the reliability of the incarceration variables from the NLSY97, which are used to distinguish ex-offenders from non-offenders.

For each labor market outcome, the first of the paired, odd-numbered columns in Table 6 shows the effects of incarceration in a repeated cross-sectional model. In these specifications, exoffenders are 8.8 percentage points less likely to be employed than non-offenders (Column 1a), have wages that are only 1.7\% less than those of non-offenders (Column 3a), and have annual earnings that are $15 \%$ less than the earnings of non-offenders (Column 5a). The differences in employment probabilities and earnings are significantly different from zero, while the difference

\footnotetext{
${ }^{18}$ Given the small number of interstate moves, state fixed effects are not included in specifications with individual fixed effects.
} 
in wages is not. As mentioned before, the result for wages may be attenuated by the ongoing relative school enrollment rate of non-offenders. Since ex-offenders and non-offenders may differ systematically in unobservable ways, a second set of specifications in Table 6 exploits the panel structure of the data with individual fixed effects. In these models, the effect of incarceration on employment is smaller in absolute value (-2.9 percentage points) and no longer significantly different from zero (Column 2a). In the panel setting, the wages of ex-offenders are $2.9 \%$ lower than those of non-offenders, but the estimate is still not significantly different from zero (Column 4a). Earnings are still lower for ex-offenders and the estimate is significantly different from zero (Column 6a).

I now turn to the estimates of the effect of the openness of criminal history records on the labor market outcomes of ex-offenders. These estimates can be found next to their respective models without the open records variables. In the repeated cross-sectional models, the sign on the estimated coefficient Access . Inc is negative for employment status and log wages, but positive for log earnings - indicating that ex-offenders are less likely to be employed, have lower wages, but higher earnings in states with Internet sites providing information about ex-offenders (Columns $1 b, 3 b$, and $5 b)$. But none of these parameter estimates is statistically significant, which suggests it is difficult to identify the relative effects of open records using only state and time variation in record openness. The specifications in the even columns additionally identify the effect of open records using individual changes in offender status. Each of these models includes individual fixed effects, but excludes the state effects and time-invariant controls. For all three labor market outcomes in the panel models, the sign of the estimated coefficient on Access . Inc is negative, indicating that ex-offenders are less likely to be employed, have lower wages, and lower earnings in states with Internet sites providing information about ex-offenders. In particular, the employment probabilities of ex-offenders are 5 percentage points lower in open-records states, but the estimate is not significantly different from zero (Column $2 \mathrm{~b}$ ). The wages of ex-offenders are $8.7 \%$ lower in open-records states, and this estimate is significantly different from zero (Column $4 b$ ). The earnings of ex-offenders are 18.7\% lower in open-records states (Column 6b). This estimate is significantly different at the 0.1 level of significance. What is striking about these estimates is that they overshadow the main effect of incarceration in those regressions. In the wage regression (Column $4 \mathrm{~b}$ ), the main effect of incarceration is indistinguishable from zero and very small rela- 
tive to the marginal effect of open records. This suggests that the availability of information about criminal histories plays a major role in determining the labor market outcomes of ex-offenders.

These results show that greater employer access to criminal histories is associated with worse labor market outcomes for ex-offenders. This evidence demonstrates the presence of imperfect information about criminal histories by employers. If employers had perfect information about the potential criminality of applicants, then greater access to criminal histories would not change the employment and wage outcomes of ex-offenders. The combination of imperfect information about applicant criminality and employer aversion to hiring ex-offenders is a strong motivation for employers to statistically discriminate. I now investigate whether such statistical discrimination occurs by examining the relative outcomes of non-offenders from highly offending groups.

\section{Expanded access to criminal history data and the labor market outcomes of ex-offenders and non-offenders}

In order to learn about whether employers statistically discriminate in the absence of criminal history data, one would like to compare the labor market outcomes of non-offenders from groups with high rates of incarceration with the labor market outcomes of groups with low rates of incarceration, and in states that have open records policies versus states that do not. In the empirical model below, I base that comparison on predicted cumulative probabilities of incarceration using variables that any prospective employer is likely to be able to observe and could use as a basis for statistical discrimination.

Suppose there is a vector of individual characteristics, given by $\mathbf{Z}$, whose elements are easily observable by potential employers and are known to be correlated with criminality or prior incarceration. If employers cannot directly observe criminality or prior incarceration, they can use these observable qualities to construct a measure of predicted or perceived criminality. One way they could do this would be to create a regression-weighted index of variables in $\mathbf{Z}$, and use this as a proxy for criminality in their hiring decisions. Since the base rates of prior incarceration are so different, I run these regressions separately for men and women. Since prior incarceration is a low-probability event, I focus on a probit model of the following form:

$$
P\left[\operatorname{Inc}_{i t}=1\right]=P\left[\alpha_{0}+\mathbf{Z}_{i t} \alpha_{1}+\eta_{i t}>0\right]=\Phi\left[\alpha_{0}+\mathbf{Z}_{i t} \alpha_{1}+\eta_{i t}\right],
$$


where $\eta_{i t}$ is an error component and $\Phi[\cdot]$ is the cumulative distribution function of the standard normal distribution. After estimating this regression, employers can predict a measure of perceived criminality: $P C_{i t} \equiv P\left[\widehat{\text { Inc }_{i t}}=1\right]=\Phi\left[\hat{\alpha}_{0}+\mathbf{Z}_{i t} \hat{\alpha}_{1}\right]$.

The vector of characteristics observable to employers, $\mathbf{Z}$, could include many variables and only some of these are observable in the NLSY97 (or any labor market survey, for that matter). ${ }^{19}$ Given the racial and ethnic disparities in incarceration, I include dummy variables for race and ethnicity. There are also substantial education differences between the incarcerated and non-incarcerated populations, so employers might also try to use educational enrollment or completion as proxies for criminality. I include indicators for school enrollment and highest degree completed and a continuous measure for years of completed schooling. Employers may consider evidence of prior labor market experience as precluding much prior incarceration, so I include the number of years of labor market experience since age 13. Employers may also use other easily observable demographic or physical characteristics as proxies for criminality, such as age, body mass index, and central-city residence. ${ }^{20} \mathrm{I}$ include these in the incarceration regressions. Since some of the respondents in the sample are still in school, I interact age with the schooling variables. Incarceration probabilities vary significantly for men by race, so the control variables in the male equation are interacted with the black and Hispanic indicators.

Table 7 shows the coefficient estimates for Equation 3 from probit regressions of the indicator for prior incarceration on the variables discussed above. I use all panel observations but do not exploit the panel structure, since those effects are unobservable to employers. Column 1 shows the coefficient estimates for men, broken down by the main effects and the racial and ethnic interaction effects. Column 2 shows the coefficient estimates for women. Current enrollment is a strong negative predictor of prior incarceration for both men and women. Black men, Hispanic men, and women that have completed high school are significantly less likely to have an incarceration record relative to those that do not finish high school. Years of labor market experience is a positive predictor of prior incarceration for black men and women, but for white and Hispanic men the coefficient estimates are not significantly different from zero. This labor market experience

\footnotetext{
${ }^{19}$ There may be very important characteristics that employers observe during the application or interview process, such as dress or speech, that may be correlated with criminality or incarceration.

${ }^{20}$ The body mass index cannot be constructed for all NLSY97 respondents because of missing data, so the BMI is demeaned and missing values are assigned a zero (i.e., the sample mean). Then a dummy is included that is equal to one if the BMI is missing for that observation, and zero otherwise.
} 
variable includes work as a minor and so the estimates for women and black men are consistent with work as a substitute for schooling. Central city residence is associated with higher cumulative probabilities of incarceration for black men, but lower cumulative probabilities for Hispanic men. A higher body mass index is associated with a lower cumulative incarceration probability, but the effect is less negative for black men. Finally, note that the coefficient estimates for the main effects of race and ethnicity in the male equation are not informative about the relationship between race and cumulative probabilities of incarceration. For women, the estimates are quite similar to the main effects for men. The exception is that there is no comparable difference in prior incarceration by race or ethnicity for women. In general, these estimates are consistent with the demographics of the incarcerated population.

Using the estimated parameters from Table 7, predicted probabilities of incarceration are generated for each person-year observation. The predicted probabilities for men and women are combined into a single measure of perceived criminality. For white men, black men, Hispanic men, and all women, Figure 4 shows the estimated kernel densities of the predicted probability of incarceration from the probit models. ${ }^{21}$ Note that the distribution contains the cumulative incarceration probabilities for the entire range of ages in the sample. Thus, the cumulative incarceration probabilities for the oldest male respondents are located in the far right tail of the distributions in Figure 4 .

Using the constructed measure of perceived criminality, the effects of open records for exoffenders and non-offenders can be estimated. For each labor market outcome $Y$, I estimate the following regression:

$$
\begin{aligned}
Y_{i s t}= & \beta_{0}+\beta_{1} P C_{i t}+\beta_{2} \text { Access }_{s t} \text { Inc }_{i s t}+\beta_{3} P C_{i t} \text { Access }_{s t} \\
& +\beta_{4} P C_{i t} \text { Access }_{s t} \text { Inc }_{i s t}+\beta_{5} P C_{i t} \text { Inc }_{i s t}+\beta_{6} \text { Access }_{s t}+\beta_{7} \text { Inc }_{i s t} \\
& +\mathbf{X}_{i s t} \beta_{8}+\gamma_{s}+\gamma_{t}+\varepsilon_{i s t},
\end{aligned}
$$

where $P C_{i t}$ is the perceived criminality index predicted from Equation 3 for individual $i$ in year $t$, and $\varepsilon$ is an error term. Equation 4 embeds the relative effects of open records on ex-offenders

\footnotetext{
${ }^{21}$ The densities are smoothed by the Epanechnikov kernel using boundary correction and the Silverman rule-ofthumb bandwidth.
} 
and on non-offenders in a single framework and allows these effects to vary by the individual's predicted criminality. This equation is an extension of the one used above to examine the model of statistical discrimination (Equation 1)-adding the control variables $\mathbf{X}$, state fixed effects $\gamma_{s}$, and time effects $\gamma_{t}$ necessary for identification. ${ }^{22}$

As before, the effects of employer access to criminal history records can be identified in two ways. In the first research design, the parameters can be identified from spatial and temporal variation in the introduction of open records. ${ }^{23}$ These specifications treat the data as pooled crosssections and use state and year fixed effects for identification. ${ }^{24}$ The repeated cross-sectional design is the one shown in Equation 4. In an alternative strategy, the parameters are identified from the changes in both offender status and perceived criminality, in addition to the state and time variation in when states began to make criminal history records available over the Internet. This design exploits the longitudinal structure of the NLSY97 and includes individual fixed effects and year effects, but excludes the state effects and time-invariant controls. The pooled cross-sectional specification is somewhat difficult to interpret without additional assumptions about the effect of perceived criminality conditional on the elements of $\mathbf{X}$, which are standard covariates included in regressions of labor market outcomes. Even with the interaction effects of perceived criminality, the estimates could be identifying changes in the return to education, for example, rather than changes in how employers perceive the risk of hiring an applicant with a particular expected value of criminal activity. For this reason, the panel regression with individual fixed effects is the preferred model because it eliminates the need to make any identifying assumptions about how the covariates directly affect the outcomes. I include the cross-sectional models because the short sample and youth of the respondents limits the variation available to identify an individual-fixedeffect regression.

Table 8 shows the estimates from Equation 4 using the two identification strategies for each labor market outcome. The odd-numbered columns show the estimates using the pooled cross-

\footnotetext{
${ }^{22}$ As in the first set of regressions of labor market outcomes, all continuous covariates in these specifications are centered by the sample means from each model's respective sample. This allows meaningful interpretation of the main effect of Access.

${ }^{23}$ It is possible to identify the effect of opening records on the labor market outcomes of ex-offenders relative to nonoffenders by using only data from states that change their policy toward criminal history records. In specifications that use this smaller sample of states, point estimates for parameters of interest are similar, but less precisely measured.

${ }^{24}$ A pre-post effect may be confounded by time trends that are specific to adopting states. To account for this, linear time trends for Census regions were included in a set of specifications as a robustness check. The estimated parameters of interest were quite similar with those shown in Table 8
} 
section identification strategy and the even-numbered columns show the estimates using the longitudinal identification strategy.

Now, recall the two primary hypotheses of the statistical discrimination model. The first hypothesis is that open records should increase the relative penalty that ex-offenders face in the labor market because they can be distinguished from non-offenders. This can be tested with the coefficient on the interaction of Access and Inc using the alternative hypothesis $\beta_{2}<0$. The second hypothesis is that open records should improve the relative outcomes of non-offenders who have high levels of perceived criminality. Restated, this is equivalent to the hypothesis that open records should harm the relative outcomes of ex-offenders who have high perceived criminality. This can be tested with the coefficient on the interaction of $P C, A c c e s s$, and Inc using the alternative hypothesis $\beta_{4}<0$.

First, focus on the estimates of $\beta_{2}$, which measures how open records affect the main effect of actual criminality. In the pooled cross-sectional models in the odd-numbered columns, the estimates of $\beta_{2}$ are positive, which is not as expected, but the estimates are very close to zero and statistically insignificant. Since there may be substantial unobservable differences between exoffenders and non-offenders, the longitudinal models in the even-numbered columns may provide more informative results. In these specifications, the estimated coefficients on Access Inc are all negative, which is consistent with the hypothesis that ex-offenders will do relatively worse in the labor market once criminal history records are easy accessible by employers. The estimate of $\beta_{2}$ is only statistically significantly different from zero, however, in the earnings regression. Although I hesitate to make strong statements given the lack of statistical significance, the signs of these effects are consistent with a statistical discrimination story in which employers continue to hire ex-offenders and ex-offenders in similar proportions after criminal records become more available, but non-offenders do start to receive somewhat higher wages than ex-offenders when employers can verify their criminal histories.

The next hypothesis from the statistical discrimination model is that non-offenders from highly offending groups should have improved labor market outcomes once employers can verify their clean criminal histories. This is the same as saying that ex-offenders from highly offending groups should have relatively worse outcomes from non-offenders from highly offending groups. This is captured by the coefficient on the interaction of perceived criminality, open records, and actual 
criminality, $\beta_{4}$. If $\beta_{4}$ is less than zero, ex-offenders do increasingly worse than non-offenders as a function of their perceived criminality. In the repeated cross-sectional models, the parameter estimates of $\beta_{4}$ are all negative, which is consistent with improved outcomes of non-offenders from highly offending groups. None of these estimates, however, are statistically significantly different from zero. In the panel models, the estimates of $\beta_{4}$ are negative for employment status and $\log$ wages, but positive for log earnings. In general, the estimates for this hypothesis are imprecisely measured but broadly consistent with the notion that employers statistically discriminate in the absence of criminal history records.

In summary, there is some evidence that expanded employer access to criminal history records has increased the difference in outcomes between non-offenders and ex-offenders-holding perceived criminality constant. There is some evidence that the labor market outcomes of nonoffenders have improved in states that have made records available over the Internet compared with the change in outcomes for non-offenders in states that did not make records available over the Internet. This suggests that the expanded outcome gap between non-offenders and exoffenders is primarily driven by the worsening outcomes of ex-offenders once records become available over the Internet.

\section{Interpreting the results}

Evidence presented above indicates that the employment effects of incarceration are more negative in states that provide criminal history records over the Internet than in states that do not. These results for ex-offenders are consistent with asymmetric information about criminal histories in labor markets. If employers had perfect information and could identify all potential criminals among applicants, then greater access to criminal history records would not cause a change in the labor market outcomes of ex-offenders. ${ }^{25}$ And evidence of imperfect information suggests that employers have a strong motivation to statistically discriminate against individuals from highly offending groups. Another important finding for ex-offenders is that the estimated effects of open records on the outcomes of ex-offenders are relatively large compared with the main effects of

\footnotetext{
${ }^{25}$ This evidence is consistent with the audit study results of Pager (2003). She finds that auditors who signaled their own incarceration record during the application phase of hiring had call-back rates that were half as large as the call-back rates for the other auditor. The relative effect of information disclosure was similar for auditors from highly incarcerated groups (blacks) and auditors from less incarcerated groups (whites).
} 
incarceration on labor market outcomes. That is, the marginal effect of opening records on the labor market outcomes of an individual who has a criminal record is larger than the main effect of the incarceration itself. This suggests that the availability of criminal history data is an important determinant of the labor market outcomes of former prisoners.

While this research provides compelling evidence that increased availability of criminal background data is associated with worse labor market outcomes for ex-offenders, evidence for its effects on non-offenders is less conclusive. Most of the estimated effects of open records on the outcomes of non-offenders are negative as expected, but none are statistically significant. There are a number of explanations for the lack of clear results for non-offenders. First, as in most studies of the differences between ex-offenders and non-offenders, there is a limited number of observations on the ex-offenders. Moreover, few ex-offender observations occur in the time period before most states adopted Internet background checks sites. ${ }^{26}$ This weakens the identification of any effects of open records, since the comparisons are primarily cross-sectional, rather than longitudinal.

The short sample period available in the current release of the NLSY97 also makes it difficult to draw conclusions about the long-term consequences of wider criminal background checking by employers. There is evidence that some ex-offenders have improved labor market outcomes immediately after conviction or prison release since they tend to seek work in spot markets for labor that have little prospect of training or earnings growth (Nagin and Waldfogel 1995, Nagin and Waldfogel 1998). In the short-run, non-offenders may also invest more in human capital and have temporarily lower employment odds and wages relative to ex-offenders. A short time frame exacerbates this problem, since estimates may give an incomplete picture of the labor market outcomes of ex-offenders relative to non-offenders. Future research should attempt to use a longer sample to investigate if estimates from the model are more consistent with statistical discrimination.

Another concern is that there is no information about the actual perceptions that employers have about who is likely to commit crime once hired. In this paper, perceived criminality is assumed to come from rational expectations based on current incarceration probabilities. That is, I assume employers are capable of making unbiased predictions of the likelihood that any appli-

\footnotetext{
${ }^{26}$ Table 9 shows the number of panel observations, by whether respondents will ever be incarcerated and by whether their states of residence provide criminal history records over the Internet.
} 
cant has a criminal record conditional on characteristics that are observable to both the employer and the econometrician. But employers may have other concerns than who has been incarcerated or they may be misinformed about the actual probabilities of criminal activity or incarceration. If employers estimate criminality with substantial error, then they are not effectively statistically discriminating, but rather they are simply discriminating against the groups for whom employers over-project a risk of crime. Economists generally argue that inaccurate forecasts should be driven out of the market by competition. But employers who face ex-offenders as applicants may be risk averse in light of negligent hiring lawsuits, and so have little incentive to improve their forecasts of criminality. This is an area where ethnographic work or audit studies may be particularly informative to establish how employers perceive the potential risk of hiring ex-offenders. Further work could examine the sensitivity of these results once one accounts for measurement error and imperfect perceptions of incarceration probabilities.

Finally, the nature of criminal history systems may lead to Type 1 and Type 2 error rates that drive effects primarily for ex-offenders but not non-offenders. One possibility is that criminal background checks have very low probabilities of false negatives, but very high probabilities of false positives. There is some concern in the government agencies that manage criminal history data systems that name-based searches of records can yield high rates of false positives (of a criminal record) and false negatives. SEARCH (1999) reports that name-based searches made through the Federal Bureau of Investigation's National Crime Information Center yielded false positives at a rate of $7.5 \%$. If false negatives are rare and employers have imperfect information about records, then greater access to criminal histories should lead to substantial negative effects for ex-offenders since it reveals damaging information previously unavailable. But if the rate of false positives is very high, then greater access to criminal histories may not cause an improvement in the labor market outcomes of non-offenders from highly offending groups even if employers statistically discriminate. Employers may consider not finding a record of little consequence if they are aware of the imperfections in the criminal records systems, so they may continue to discount the productivity of individuals with high predicted criminality. This effect would be exacerbated if there is more similarity of names within narrow racial and social classes. ${ }^{27}$ Therefore, this type of asym-

\footnotetext{
${ }^{27}$ The observation that some names are common within racial groups, but not across them, is the basis of Bertrand and Mullainathan's (2004) correspondence audit study of discrimination in hiring.
} 
metric precision of criminal background checks is consistent with the evidence in this paper but also with statistical discrimination by employers.

Some of the concerns discussed here apply generally to empirical studies of statistical discrimination and their implications should be considered when researcher try to interpret the magnitude of estimated effects of statistical discrimination.

\section{Conclusion}

This paper examines how expanded employer access to criminal history data influences the labor market outcomes of ex-offenders and non-offenders. I find evidence that employment effects of incarceration are more negative in states that provide criminal history records over the Internet than in states that do not. There is also evidence that ex-offenders in states with open records policies have lower wages and earnings than ex-offenders in states with more closed records policies. There is less conclusive evidence that labor market outcomes of non-offenders from highly offending groups are improved by greater employer access to criminal history data. While the estimates are consistent with the theoretical prediction, the estimated effects for non-offenders are not estimated precisely enough to draw strong conclusions about whether employers statistically discriminate to avoid hiring ex-offenders. One explanation for these results is that the sample period is too short to capture the long-term effects of opening criminal history records to the public. Another explanation is that the nature of false-positive and false-negative criminal check results generates significant effects for ex-offenders but not non-offenders. Nevertheless, the empirical methods used in this analysis are a fruitful way for examining the extent of statistical discrimination when there are changes in the information set available to employers during hiring.

This research is important for understanding why released prisoners experience poor labor market outcomes. The labor market outcomes of ex-offenders are a public finance concern because failure to gain legitimate employment after prison release is a strong predictor of recidivism, which is costly for prison systems. Regression estimates indicate that more widely available criminal history data worsens the labor market outcomes of ex-offenders. In fact, in some specifications, the effect of open records on ex-offenders trumps the main effect of being an ex-offender, suggesting that the information available to employers has a major impact on how ex-offenders re- 
integrate into the legitimate labor force. This research also highlights how the high relative rates of incarceration for black and Hispanic men may affect the employment outcomes of non-offenders from those groups. One of the expected benefits of an open-records system is that informational symmetry should help non-offenders from highly offending groups. I do not find statistically significant evidence of this effect, but further research should continue to address this potential side effect of providing criminal history records over the Internet.

A criminal background check is, however, just one type of pre-employment screen that has become more convenient for employers to carry out because of technological changes. Our personal information is increasingly available over the Internet and some of this information can be used in the hiring process. For example, personal credit reports are used by some employers to gauge the financial responsibility of applicants (Arnoldy 2007). Some human resource managers also search peer-to-peer websites like MySpace for revealing information about potential employees, especially recent college graduates with little labor market history (Finder 2006). The productivity basis for some screens may be obvious, such as driving record checks for commercial truck drivers, but for other screens the connection to productivity may be less clear. The research design in this paper could serve as a useful strategy for measuring the effects of these types of technologies that expand the information sets available to employers during hiring. 


\section{References}

Abe, Yasuyo. 2001. Changes in Gender and Racial Gaps in Adolescent Antisocial Behavior: The NLSY97 versus the NLSY79. In Robert T. Michael, editor, Social Awakening: Adolescent Behavior as Adulthood Approaches. New York: Russell Sage Foundation.

Andler, Edward C. and Dara Herbst. 2003. The Complete Reference Checking Handbook. New York: American Management Association.

Arnoldy, Ben. 2007. The Spread of the Credit Check as Civil Rights Issue. The Christian Science Monitor 18 January 2007. http://www.csmonitor.com/2007/0118/p01s03-ussc.html (accessed on 1 July 2007).

Autor, David H. and David Scarborough. 2008. Will Job Testing Harm Minority Workers? Evidence from the Retail Sector. Quarterly Journal of Economics 123(1): 219-77.

Bertrand, Marianne and Sendhil Mullainathan. 2004. Are Emily and Greg More Employable than Lakisha and Jamal? A Field Experiment on Labor Market Discrimination. American Economic Review 94(4): 991-1013.

Bonczar, Thomas P. 2003. Prevalence of Imprisonment in the U.S. Population, 1974-2001. Bureau of Justice Statistics, NCJ 197976.

Bonczar, Thomas P. and Allen J. Beck. 1997. Lifetime Likelihood of Going to State or Federal Prison. Bureau of Justice Statistics, NCJ 160092.

Brien, Peter M. 2005. Improving Access and Integrity of Criminal History Records. Bureau of Justice Statistics, NCJ 200581.

Burke, Mary Elizabeth. 2005. 2004 Reference and Background Checking Survey Report. Alexandria, VA: Society for Human Resource Management.

Bushway, Shawn, Shauna Briggs, Faye Taxman, Meridith Thanner, and Mischelle Van Brakle. 2007. Private Providers of Criminal History Records: Do You Get What You Pay For? In Shawn Bushway, Michael A. Stoll, and David F. Weiman, editors, Barriers to Reentry? The Labor Market for Released Prisoners in Post-Industrial America. New York: Russell Sage Foundation.

Bushway, Shawn D. 1996. The Impact of a Criminal History Record on Access to Legitimate Employment. Ph.D. dissertation, Carnegie Mellon University, Pittsburgh.

- 2004. Labor Market Effects of Permitting Employer Access to Criminal Records. Journal of Contemporary Criminal Justice 20(3): 276-91.

Cho, Rosa and Robert LaLonde. 2005. The Impact of Incarceration in State Prison on the Employment Prospects of Women. Institute for the Study of Labor (IZA) Discussion Paper 1792.

Connerley, Mary L., Richard D. Arvey, and Charles J. Bernardy. 2001. Criminal Background Checks for Prospective and Current Employees: Current Practices among Municipal Agencies. Public Personnel Management 20(2): 173-84.

Equal Employment Opportunity Commission. 1987a. Policy Statement on the Issue of Conviction Records under Title VII of the Civil Rights Act of 1964. Notice N-915. 
1987b. Policy Statement on the Use of Statistics in Charges Involving the Exclusion of Individuals with Conviction Records from Employment. Notice N-915-061.

Finder, Alan. 2006. For Some, Online Persona Undermines a Résumé. The New York Times 11 June 2006. http://www.nytimes.com/2006/06/11/us/11recruit.html (accessed on 1 July 2007).

Grogger, Jeffrey. 1995. The Effect of Arrests on the Employment and Earnings of Young Men. Quarterly Journal of Economics 110(1): 51-71.

Harrison, Paige M. and Allen J. Beck. 2006. Prison and Jail Inmates at Midyear 2005. Bureau of Justice Statistics, NCJ 213133.

Hindelang, Michael J., Travis Hirschi, and Joseph G. Weis. 1981. Measuring Delinquency. Beverly Hills, CA: Sage Publications.

Hinton, Derek. 2004. The Criminal Records Manual. Tempe, AZ: Facts on Demand Press.

Hjalmarsson, Randi. 2008. Criminal Justice Involvement and High School Completion. Journal of Urban Economics 63(2): 613-30.

Holzer, Harry J., Steven Raphael, and Michael A. Stoll. 2006. Perceived Criminality, Criminal Background Checks, and the Racial Hiring Practices of Employers. Journal of Law and Economics 49(2): 451-80.

. 2007. The Effect of an Applicant's Criminal History on Employer Hiring Decisions and Screening Practices: Evidence from Los Angeles. In Shawn Bushway, Michael A. Stoll, and David F. Weiman, editors, Barriers to Reentry? The Labor Market for Released Prisoners in PostIndustrial America. New York: Russell Sage Foundation.

Johnson, Pamela R. and Julie Indvik. 1994. Workplace Violence: An Issue of the Nineties. Public Personnel Management 23(4): 515-23.

Kling, Jeffrey R. 2006. Incarceration Length, Employment, and Earnings. American Economic Review 96(3): 863-76.

Legal Action Center. 2004. After Prison: Roadblocks to Reentry: A Report on State Legal Barriers facing People with Criminal Records. http://www. lac. org/lac (accessed on 7 October 2005).

Lochner, Lance. 2007. Individual Perceptions of the Criminal Justice System. American Economic Review 97(1): 444-60.

Nagin, Daniel and Joel Waldfogel. 1995. The Effects of Criminality and Conviction on the Labor Market Status of Young British Offenders. International Review of Law and Economics 15(1): 109-26.

- 1998. The Effect of Conviction on Income through the Life Cycle. International Review of Law and Economics 18(1): 25-40.

Needels, Karen E. 1996. Go Directly to Jail and Do Not Collect? A Long-Term Study of Recidivism, Employment, and Earnings Patterns among Prison Releases. Journal of Research in Crime and Delinquency 33(4): 471-96.

Odewahn, Charles A. and Darryl L. Webb. 1989. Negligent Hiring and Discrimination: An Employer's Dilemma? Labor Law Journal 40(11): 705-12. 
Pager, Devah. 2003. The Mark of a Criminal Record. American Journal of Sociology 108(5): 937-75.

Raphael, Steven. 2006. The Socioeconomic Status of Black Males: The Increasing Importance of Incarceration. In Alan Auerbach, David Card, and John Quigley, editors, Poverty, the Distribution of Income, and Public Policy. New York: Russell Sage Foundation.

Rosen, Lester S. 2006. The Safe Hiring Manual. Tempe, AZ: Facts on Demand Press.

Sampson, Robert J. and John H. Laub. 1993. Crime in the Making: Pathways and Turning Points through Life. Cambridge, MA: Harvard University Press.

SEARCH, The National Consortium for Justice Information and Statistics. 1994. Survey of Criminal History Information Systems, 1993. Bureau of Justice Statistics, NCJ 148951.

- 1999. Interstate Identification Index Name Check Efficacy. Bureau of Justice Statistics, NCJ 179358.

—. 2001. Internet Computerized Criminal History Survey. Sacramento, CA: Author.

— 2006. State Criminal History Record Information Availability Survey. Sacramento, CA: Author.

Uggen, Christopher. 2000. Work as a Turning Point in the Life Course of Criminals: A Duration Model of Age, Employment, and Recidivism. American Sociological Review 65(4): 529-46.

Viscusi, W. Kip. 1986. Market Incentives for Criminal Behavior. In Richard Freeman and Harry Holzer, editors, Black Youth Employment Crisis. Chicago: University of Chicago Press.

Western, Bruce. 2002. The Impact of Incarceration on Wage Mobility and Inequality. American Sociological Review 67(4): 526-46. 


\section{Figures and tables}

Figure 1: States that distribute criminal history records over the Internet (and the first year they did so)

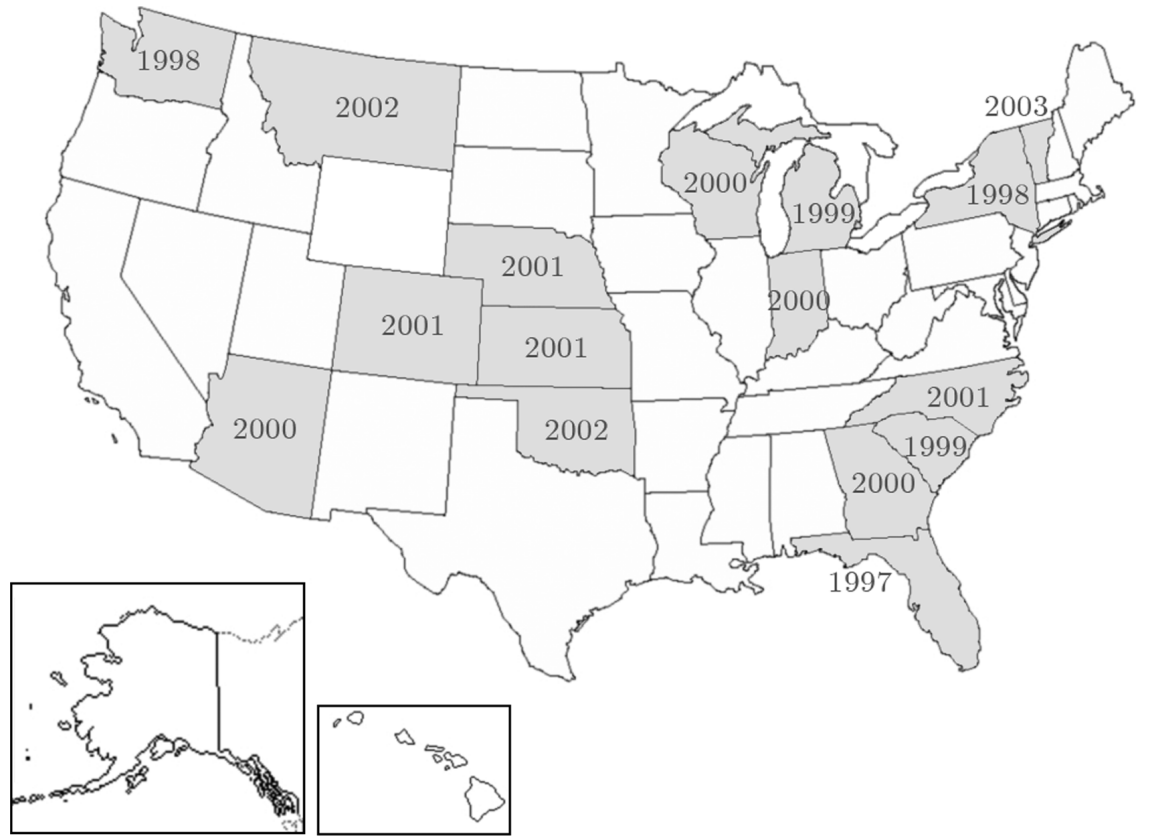

Notes:

- States are shaded if they distribute the criminal history records of released prisoners over a publicly accessible Internet site.

- Data collected by author, starting from a cross section available in Legal Action Center (2004). 
Figure 2: Statistical discrimination model with criminal history records Panel A: criminal records not publicly available

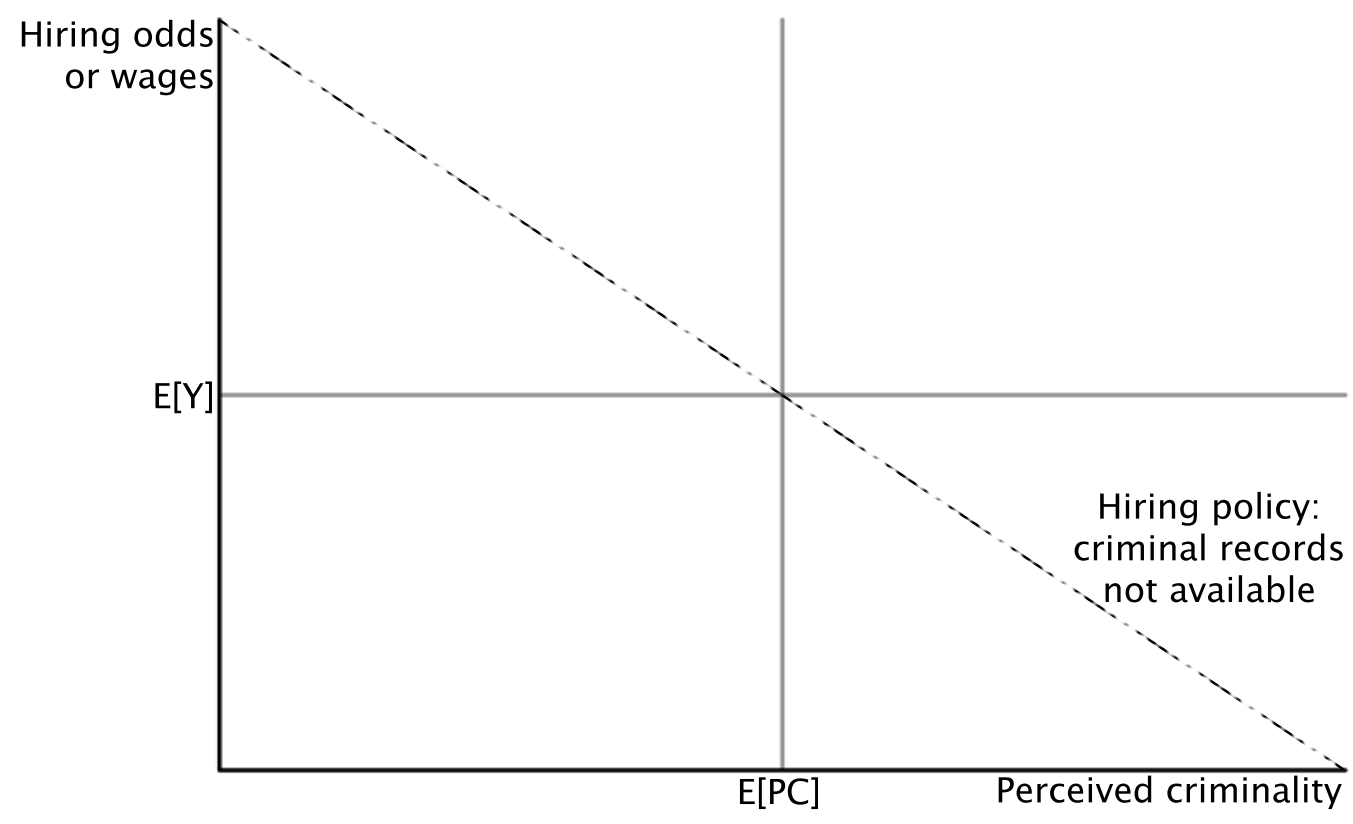

Panel B: criminal records available

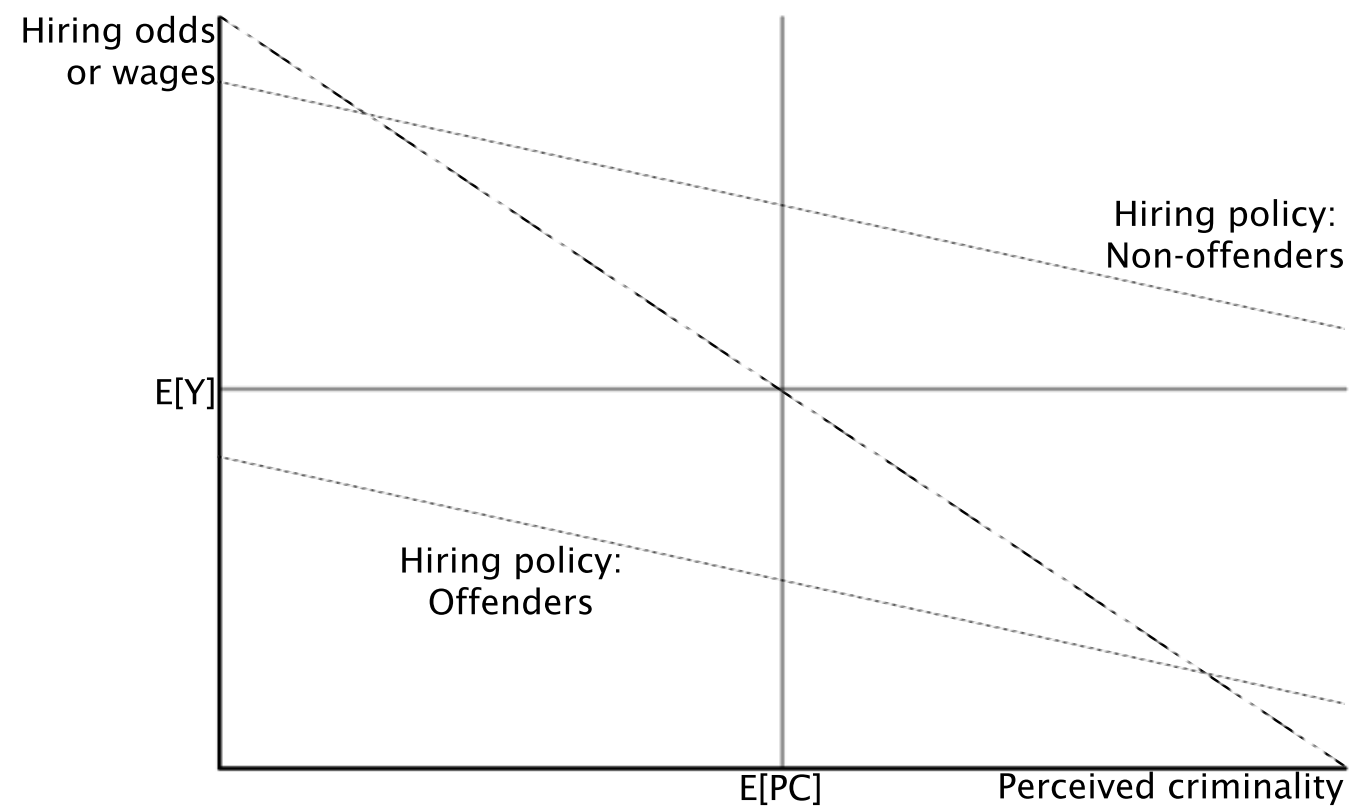


Figure 3: Cumulative proportion of NLSY97 respondents who have been incarcerated as an adult by age, gender, and race/ethnicity, 1997-2004

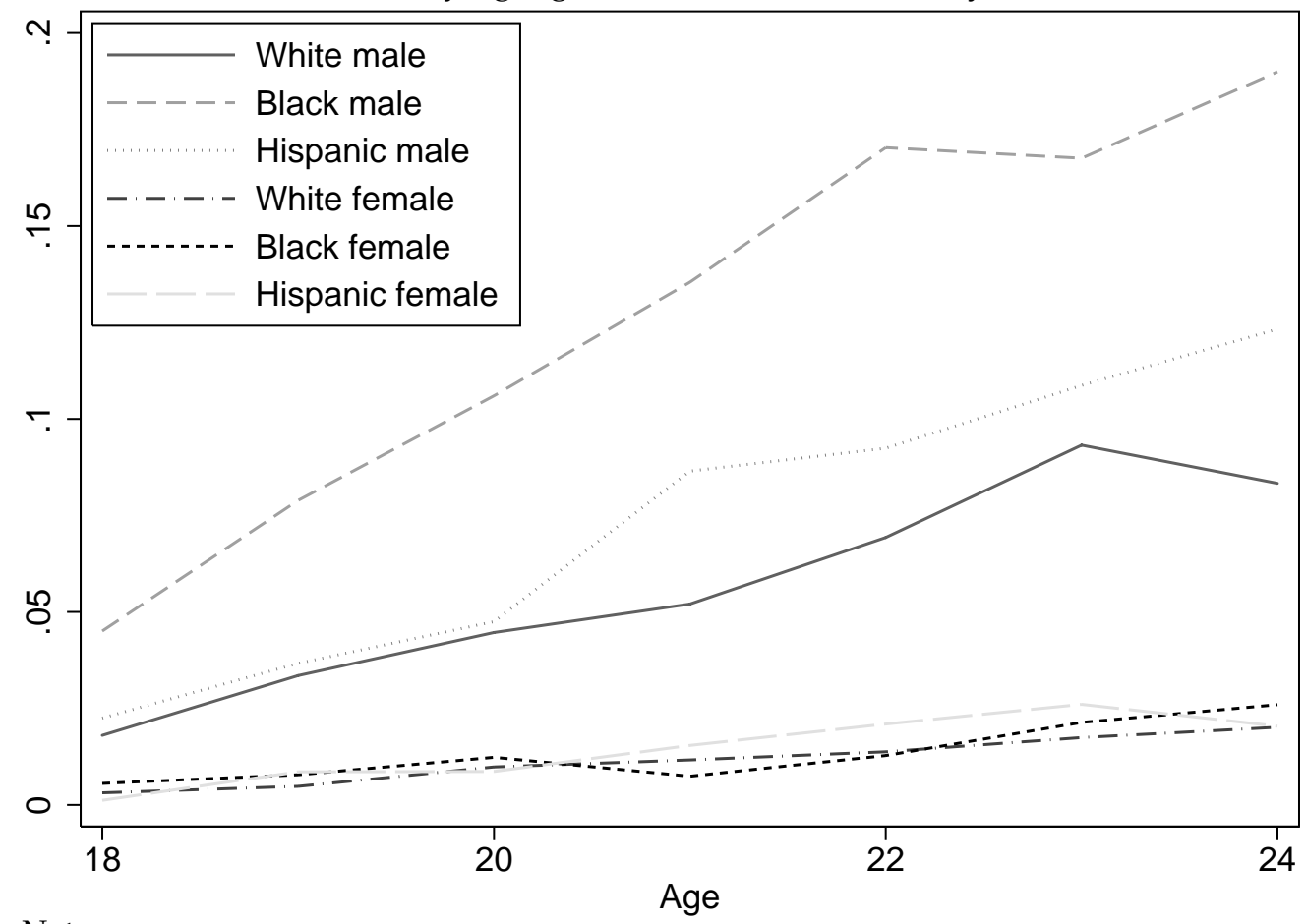

Notes:

- Plot shows the cumulative proportion of each subsample that has been incarcerated as an adult by the appropriate age.

- Age 25 is excluded because of small sample sizes.

- Lines are not all monotonic because not all respondents reach 24 years of age by the end of the sample, some respondents miss interviews, and some respondents attrit. 
Figure 4: Estimated kernel densities of predicted probability of incarceration, by race and ethnicity (for men) and gender, NLSY97 respondents aged 18-25 years, 1997-2004

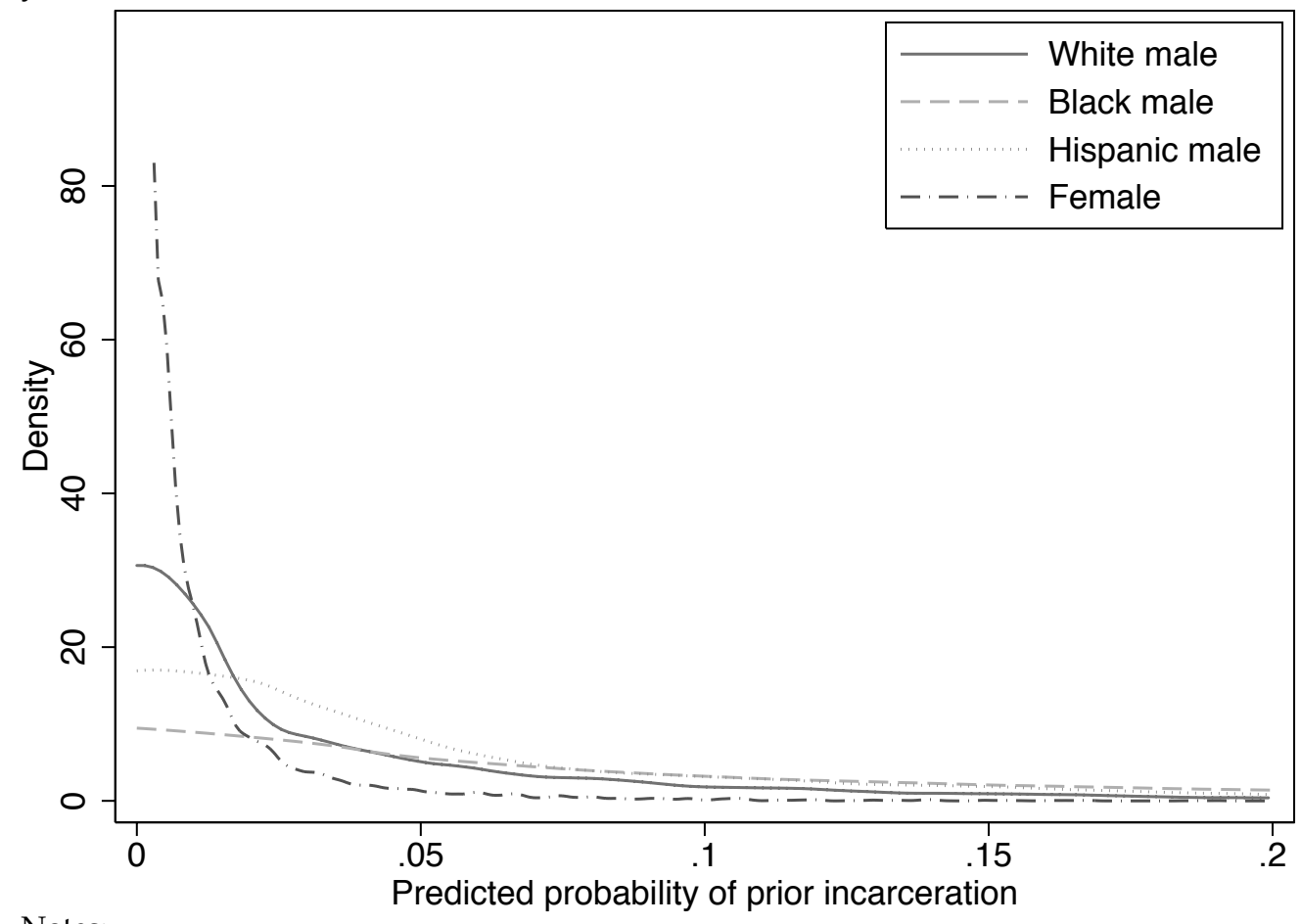

Notes:

- Densities are smoothed by the Epanechnikov kernel using boundary correction and the Silverman rule-of-thumb bandwidth.

- Predictions are from the male and female models in Table 7 
Table 1: Number of NLSY97 respondents aged 18 years or older, by age and survey year, 1997-2004

\begin{tabular}{crrrrrrrrr}
\hline \hline Ages & 1997 & \multicolumn{1}{c}{1998} & \multicolumn{1}{c}{1999} & 2000 & 2001 & 2002 & 2003 & 2004 & Total \\
\hline 18 & 21 & 1,407 & 1,618 & 1,648 & 1,597 & 1,613 & 113 & 0 & 7,996 \\
19 & 0 & 109 & 1,380 & 1,595 & 1,587 & 1,583 & 1,497 & 52 & 7,803 \\
20 & 0 & 0 & 67 & 1,381 & 1,560 & 1,638 & 1,597 & 1,444 & 7,687 \\
21 & 0 & 0 & 0 & 133 & 1,318 & 1,576 & 1,583 & 1,508 & 6,118 \\
22 & 0 & 0 & 0 & 0 & 108 & 1,322 & 1,559 & 1,551 & 4,540 \\
23 & 0 & 0 & 0 & 0 & 0 & 111 & 1,291 & 1,524 & 2,926 \\
24 & 0 & 0 & 0 & 0 & 0 & 0 & 79 & 1,288 & 1,367 \\
25 & 0 & 0 & 0 & 0 & 0 & 0 & 0 & 97 & 97 \\
\hline Total & 21 & 1,516 & 3,065 & 4,757 & 6,170 & 7,843 & 7,719 & 7,464 & 38,555 \\
\hline
\end{tabular}

Table 2: NLSY97 sample restrictions

\begin{tabular}{|c|c|c|}
\hline Iterative sample restrictions & $\begin{array}{c}\text { Panel } \\
\text { Observations }\end{array}$ & Individuals \\
\hline \multirow[t]{2}{*}{ Completed interviews } & 64,336 & 8,984 \\
\hline & $-25,781$ & -325 \\
\hline \multirow[t]{2}{*}{ Aged 18 or more years } & 38,555 & 8,659 \\
\hline & $-1,439$ & -325 \\
\hline \multirow[t]{2}{*}{ White, black, or Hispanic } & 37,116 & 8,334 \\
\hline & -2 & -2 \\
\hline \multirow[t]{2}{*}{ Nonzero sampling weights } & 37,114 & 8,332 \\
\hline & -427 & -28 \\
\hline \multirow[t]{2}{*}{ Not incarcerated during interview } & 36,687 & 8,304 \\
\hline & -359 & -359 \\
\hline $\begin{array}{l}\text { More than one interview } \\
\text { (effective variation for individual } \\
\text { fixed effects models) }\end{array}$ & 36,328 & 7,945 \\
\hline
\end{tabular}


Table 3: Selected descriptive statistics of variables from the last survey round in which each NLSY97 respondent participated, by adult incarceration history

\begin{tabular}{|c|c|c|c|}
\hline Variable & $\begin{array}{c}\text { All } \\
\text { respondents }\end{array}$ & $\begin{array}{c}\text { Incarcerated } \\
\text { as an adult }\end{array}$ & $\begin{array}{c}\text { Not } \\
\text { incarcerated } \\
\text { as an adult } \\
\end{array}$ \\
\hline \multirow[t]{2}{*}{ Employment status } & 0.72 & 0.59 & 0.72 \\
\hline & 8,304 & 369 & 7,935 \\
\hline \multirow[t]{3}{*}{ Hourly wage } & 12.15 & 11.85 & 12.16 \\
\hline & $(6.54)$ & $(5.80)$ & $(6.57)$ \\
\hline & 6,744 & 290 & 6,454 \\
\hline \multirow[t]{3}{*}{ Annual earnings } & 10402.22 & 7304.67 & 10546.74 \\
\hline & $(12010.67)$ & $(8824.73)$ & $(12120.02)$ \\
\hline & 8,166 & 364 & 7,802 \\
\hline \multirow[t]{2}{*}{ Ever incarcerated as an adult } & 0.04 & 1.00 & 0.00 \\
\hline & 8,304 & 369 & 7,935 \\
\hline \multirow[t]{3}{*}{ Age } & 21.74 & 22.22 & 21.72 \\
\hline & $(1.57)$ & $(1.52)$ & $(1.57)$ \\
\hline & 8,304 & 369 & 7,935 \\
\hline \multirow{3}{*}{ Highest grade completed } & 12.80 & 11.21 & 12.87 \\
\hline & $(1.90)$ & $(1.61)$ & $(1.88)$ \\
\hline & 8,304 & 369 & 7,935 \\
\hline \multirow[t]{2}{*}{ Currently enrolled in school } & 0.30 & 0.08 & 0.31 \\
\hline & 8,304 & 369 & 7,935 \\
\hline \multirow[t]{2}{*}{ Has GED } & 0.06 & 0.19 & 0.05 \\
\hline & 8,304 & 369 & 7,935 \\
\hline \multirow[t]{2}{*}{ Has HS diploma } & 0.67 & 0.32 & 0.69 \\
\hline & 8,304 & 369 & 7,935 \\
\hline \multirow[t]{2}{*}{ Has associates } & 0.03 & 0.01 & 0.03 \\
\hline & 8,304 & 369 & 7,935 \\
\hline \multirow[t]{2}{*}{ Has bachelors or more } & 0.08 & 0.04 & 0.08 \\
\hline & 8,304 & 369 & 7,935 \\
\hline Years of school attended & 8.70 & 9.17 & 8.68 \\
\hline \multirow[t]{2}{*}{ since age 13} & $(1.55)$ & $(1.49)$ & $(1.55)$ \\
\hline & 8,304 & 369 & 7,935 \\
\hline Years of labor market & 7 & 7 & 7 \\
\hline \multirow[t]{2}{*}{ experience since age 13} & 2 & 3 & 2 \\
\hline & 8,304 & 369 & 7,935 \\
\hline Armed Services Vocational & 45 & 28 & 46 \\
\hline \multirow[t]{2}{*}{ Aptitude Battery score } & 29 & 25 & 29 \\
\hline & 6,642 & 270 & 6,372 \\
\hline \multirow{2}{*}{$\begin{array}{l}\text { Lives in state with criminal } \\
\text { records Internet site }\end{array}$} & 0.37 & 0.39 & 0.37 \\
\hline & 8,304 & 369 & 7,935 \\
\hline \multicolumn{4}{|c|}{$\begin{array}{l}\text { Notes: } \\
\text { - Cells contain the mean, standard deviation, and number of non-missing } \\
\text { observations for each variable within the given sample. } \\
\text { - The sample used to generate these descriptive statistics excludes } \\
\text { individuals who are incarcerated at the time of their interviews. See } \\
\text { Table } 2 \text { for a complete description of the sample restrictions. }\end{array}$} \\
\hline
\end{tabular}


Table 4: Percentage of NLSY97 respondents who report having been incarcerated as an adult since the date of their last interview, by age, gender, and race/ethnicity, 19972004

\begin{tabular}{|c|c|c|c|c|c|c|c|}
\hline \multirow[b]{2}{*}{ Subsample } & \multicolumn{7}{|c|}{ Respondent age } \\
\hline & 18 & 19 & 20 & 21 & 22 & 23 & 24 \\
\hline \multirow[t]{2}{*}{ White males } & 1.80 & 2.18 & 2.13 & 1.82 & 2.34 & 1.98 & 0.96 \\
\hline & $\mathrm{n}=1996$ & $\mathrm{n}=1969$ & $n=1925$ & $\mathrm{n}=1537$ & $\mathrm{n}=1111$ & $\mathrm{n}=708$ & $\mathrm{n}=312$ \\
\hline \multirow[t]{2}{*}{ Black males } & 4.51 & 5.92 & 7.03 & 7.85 & 8.18 & 6.38 & 7.82 \\
\hline & $n=1043$ & $\mathrm{n}=1014$ & $\mathrm{n}=981$ & $\mathrm{n}=790$ & $\mathrm{n}=599$ & $\mathrm{n}=376$ & $\mathrm{n}=179$ \\
\hline \multirow[t]{2}{*}{ Hispanic males } & 2.25 & 2.57 & 2.75 & 4.40 & 2.94 & 3.11 & 1.37 \\
\hline & $\mathrm{n}=844$ & $\mathrm{n}=818$ & $\mathrm{n}=800$ & $\mathrm{n}=659$ & $\mathrm{n}=476$ & $\mathrm{n}=322$ & $\mathrm{n}=146$ \\
\hline \multirow[t]{2}{*}{ White females } & 0.32 & 0.21 & 0.49 & 0.41 & 0.28 & 0.15 & 1.01 \\
\hline & $n=1903$ & $\mathrm{n}=1866$ & $\mathrm{n}=1829$ & $\mathrm{n}=1458$ & $\mathrm{n}=1089$ & $n=687$ & $\mathrm{n}=298$ \\
\hline \multirow[t]{2}{*}{ Black females } & 0.56 & 0.49 & 0.38 & 0.50 & 0.32 & 0.48 & 0.43 \\
\hline & $\mathrm{n}=1076$ & $\mathrm{n}=1023$ & $\mathrm{n}=1053$ & $\mathrm{n}=807$ & $\mathrm{n}=625$ & $\mathrm{n}=421$ & $\mathrm{n}=231$ \\
\hline \multirow[t]{2}{*}{ Hispanic females } & 0.12 & 0.74 & 0.37 & 0.77 & 0.42 & 0.65 & 0.00 \\
\hline & $n=833$ & $\mathrm{n}=815$ & $\mathrm{n}=807$ & $\mathrm{n}=648$ & $\mathrm{n}=477$ & $\mathrm{n}=307$ & $\mathrm{n}=147$ \\
\hline
\end{tabular}


Table 5: Cumulative percentage of NLSY97 respondents who report having been incarcerated as an adult by interview date, by age, gender, and race/ethnicity, 19972004

\begin{tabular}{|c|c|c|c|c|c|c|c|}
\hline \multirow[b]{2}{*}{ Subsample } & \multicolumn{7}{|c|}{ Respondent age } \\
\hline & 18 & 19 & 20 & 21 & 22 & 23 & 24 \\
\hline \multirow[t]{2}{*}{ White males } & 1.80 & 3.35 & 4.47 & 5.20 & 6.93 & 9.32 & 8.33 \\
\hline & $\mathrm{n}=1996$ & $n=1969$ & $\mathrm{n}=1925$ & $n=1537$ & $\mathrm{n}=1111$ & $\mathrm{n}=708$ & $\mathrm{n}=312$ \\
\hline \multirow[t]{2}{*}{ Black males } & 4.51 & 7.89 & 10.60 & 13.54 & 17.03 & 16.76 & 18.99 \\
\hline & $n=1043$ & $\mathrm{n}=1014$ & $\mathrm{n}=981$ & $\mathrm{n}=790$ & $n=599$ & $\mathrm{n}=376$ & $\mathrm{n}=179$ \\
\hline \multirow[t]{2}{*}{ Hispanic males } & 2.25 & 3.67 & 4.75 & 8.65 & 9.24 & 10.87 & 12.33 \\
\hline & $\mathrm{n}=844$ & $\mathrm{n}=818$ & $\mathrm{n}=800$ & $\mathrm{n}=659$ & $\mathrm{n}=476$ & $\mathrm{n}=322$ & $\mathrm{n}=146$ \\
\hline \multirow[t]{2}{*}{ White females } & 0.32 & 0.48 & 0.98 & 1.17 & 1.38 & 1.75 & 2.01 \\
\hline & $n=1903$ & $\mathrm{n}=1866$ & $\mathrm{n}=1829$ & $n=1458$ & $\mathrm{n}=1089$ & $\mathrm{n}=687$ & $\mathrm{n}=298$ \\
\hline \multirow[t]{2}{*}{ Black females } & 0.56 & 0.78 & 1.23 & 0.74 & 1.28 & 2.14 & 2.60 \\
\hline & $\mathrm{n}=1076$ & $n=1023$ & $n=1053$ & $\mathrm{n}=807$ & $n=625$ & $\mathrm{n}=421$ & $\mathrm{n}=231$ \\
\hline \multirow[t]{2}{*}{ Hispanic females } & 0.12 & 0.86 & 0.87 & 1.54 & 2.10 & 2.61 & 2.04 \\
\hline & $\mathrm{n}=833$ & $\mathrm{n}=815$ & $\mathrm{n}=807$ & $\mathrm{n}=648$ & $n=477$ & $\mathrm{n}=307$ & $\mathrm{n}=147$ \\
\hline \multicolumn{8}{|c|}{$\begin{array}{l}\text { Notes: } \\
\text { - Each cell contains the cumulative percentage of respondents who have been incarcerated as an adul } \\
\text { by the given age and the sample size. } \\
\text { - Age } 25 \text { is excluded because of small sample sizes. } \\
\text { - Proportions are not all monotonically increasing because not all respondents reach age } 24 \text { by the end of } \\
\text { the sample, some respondents miss interviews, and there is attrition. }\end{array}$} \\
\hline
\end{tabular}




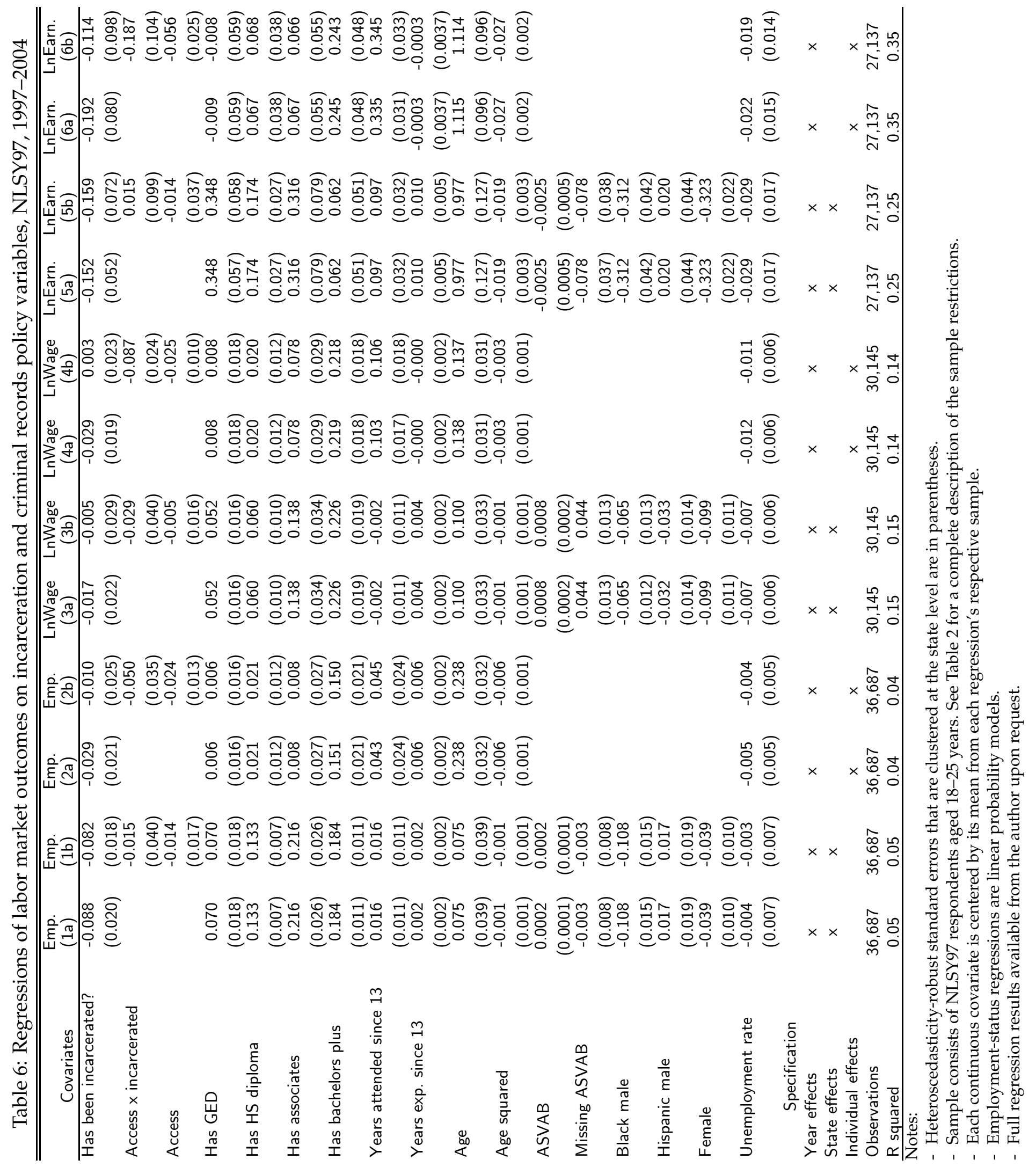


Table 7: Coefficient estimates from probit regressions of prior adult incarceration on variables observable by employers, by gender, NLSY97, 1997-2004

\begin{tabular}{|c|c|c|c|c|}
\hline \multirow[b]{2}{*}{ Covariates } & \multicolumn{4}{|c|}{ "Dependent variable: Ever incarcerated as a adult } \\
\hline & \multicolumn{3}{|c|}{ (1) Men } & \multirow[t]{2}{*}{ (2) Women } \\
\hline & Main effects & $\begin{array}{c}\text { Black } \\
\text { interactions }\end{array}$ & $\begin{array}{l}\text { Hispanic } \\
\text { interactions }\end{array}$ & \\
\hline \multirow[t]{2}{*}{ Enrolled } & -0.435 & -0.087 & -0.032 & -0.438 \\
\hline & $(0.076)$ & $(0.116)$ & $(0.142)$ & $(0.101)$ \\
\hline \multirow[t]{2}{*}{ Highest grade completed } & -0.300 & 0.014 & 0.179 & -0.140 \\
\hline & $(0.027)$ & $(0.040)$ & $(0.047)$ & $(0.026)$ \\
\hline \multirow[t]{2}{*}{ At least high school grad. } & 0.088 & -0.160 & -0.614 & -0.353 \\
\hline & $(0.093)$ & $(0.135)$ & $(0.151)$ & $(0.104)$ \\
\hline \multirow[t]{2}{*}{ At least a BA } & 0.174 & 0.083 & -0.505 & -0.110 \\
\hline & $(0.198)$ & $(0.290)$ & $(0.364)$ & $(0.220)$ \\
\hline \multirow{2}{*}{$\begin{array}{l}\text { Years of labor market experience } \\
\text { since age } 13\end{array}$} & 0.015 & 0.049 & 0.003 & 0.040 \\
\hline & $(0.012)$ & $(0.019)$ & $(0.023)$ & $(0.016)$ \\
\hline \multirow[t]{2}{*}{ Lives in central city of MSA } & -0.026 & 0.189 & -0.253 & 0.063 \\
\hline & $(0.059)$ & $(0.081)$ & $(0.097)$ & $(0.067)$ \\
\hline \multirow[t]{2}{*}{ Body mass index } & -0.028 & 0.010 & 0.012 & -0.006 \\
\hline & $(0.005)$ & $(0.005)$ & $(0.009)$ & $(0.006)$ \\
\hline \multirow[t]{2}{*}{ Missing body mass index } & -0.594 & -0.014 & -0.001 & -0.454 \\
\hline & $(0.129)$ & $(0.026)$ & $(0.028)$ & $(0.229)$ \\
\hline \multirow[t]{2}{*}{ Age } & 0.188 & -0.032 & -0.047 & 0.119 \\
\hline & $(0.017)$ & $(0.142)$ & $(0.558)$ & $(0.022)$ \\
\hline \multirow[t]{2}{*}{ Black } & -0.047 & & & -0.008 \\
\hline & $(0.558)$ & & & $(0.075)$ \\
\hline \multirow[t]{2}{*}{ Hispanic } & -1.852 & & & -0.083 \\
\hline & $(0.670)$ & & & $(0.080)$ \\
\hline Pseudo $\mathrm{R}^{2}$ & 0.18 & & & 0.14 \\
\hline Observations & 18,657 & & & 18,457 \\
\hline Proportion ever incarcerated & 0.06 & & & 0.01 \\
\hline \multicolumn{5}{|l|}{$\begin{array}{l}\text { Notes: } \\
\text { - Probit }\end{array}$} \\
\hline
\end{tabular}


Table 8: Regressions of labor market outcomes on criminal records policy variables and perceived criminality, NLSY97, 1997-2004

\begin{tabular}{|c|c|c|c|c|c|c|}
\hline Covariates & $\begin{array}{c}\text { Emp. } \\
(1)\end{array}$ & $\begin{array}{c}\text { Emp. } \\
(2)\end{array}$ & $\begin{array}{c}\text { LnWage } \\
\text { (3) }\end{array}$ & $\begin{array}{c}\text { LnWage } \\
(4)\end{array}$ & $\begin{array}{c}\text { LnEarn. } \\
\text { (5) }\end{array}$ & $\begin{array}{c}\text { LnEarn. } \\
(6)\end{array}$ \\
\hline$P C\left(\beta_{1}\right)$ & $\begin{array}{c}0.342 \\
(0.095)\end{array}$ & $\begin{array}{c}0.084 \\
(0.119)\end{array}$ & $\begin{array}{c}0.266 \\
(0.067)\end{array}$ & $\begin{array}{l}-0.078 \\
(0.083)\end{array}$ & $\begin{array}{c}1.759 \\
(0.213)\end{array}$ & $\begin{array}{c}0.735 \\
(0.298)\end{array}$ \\
\hline Access $\times \operatorname{lnc}\left(\beta_{2}\right)$ & $\begin{array}{c}0.013 \\
(0.038)\end{array}$ & $\begin{array}{l}-0.028 \\
(0.043)\end{array}$ & $\begin{array}{c}0.036 \\
(0.044)\end{array}$ & $\begin{array}{l}-0.036 \\
(0.042)\end{array}$ & $\begin{array}{c}0.090 \\
(0.170)\end{array}$ & $\begin{array}{l}-0.319 \\
(0.136)\end{array}$ \\
\hline$P C \times$ Access $\left(\beta_{3}\right)$ & $\begin{array}{l}-0.169 \\
(0.159)\end{array}$ & $\begin{array}{c}0.146 \\
(0.143)\end{array}$ & $\begin{array}{l}-0.246 \\
(0.097)\end{array}$ & $\begin{array}{l}-0.114 \\
(0.123)\end{array}$ & $\begin{array}{l}-0.185 \\
(0.352)\end{array}$ & $\begin{array}{c}0.047 \\
(0.356)\end{array}$ \\
\hline$P C \times$ Access $\times \operatorname{lnc}\left(\beta_{4}\right)$ & $\begin{array}{l}-0.095 \\
(0.255)\end{array}$ & $\begin{array}{l}-0.258 \\
(0.324)\end{array}$ & $\begin{array}{l}-0.282 \\
(0.338)\end{array}$ & $\begin{array}{l}-0.298 \\
(0.278)\end{array}$ & $\begin{array}{l}-0.351 \\
(1.170)\end{array}$ & $\begin{array}{c}1.094 \\
(1.084)\end{array}$ \\
\hline$P C \times \operatorname{lnc}\left(\beta_{5}\right)$ & $\begin{array}{l}-0.131 \\
(0.188)\end{array}$ & $\begin{array}{c}0.148 \\
(0.267)\end{array}$ & $\begin{array}{l}-0.179 \\
(0.207)\end{array}$ & $\begin{array}{l}-0.053 \\
(0.173)\end{array}$ & $\begin{array}{l}-1.591 \\
(0.381)\end{array}$ & $\begin{array}{l}-1.635 \\
(0.573)\end{array}$ \\
\hline Access $\left(\beta_{6}\right)$ & $\begin{array}{l}-0.027 \\
(0.015)\end{array}$ & $\begin{array}{l}-0.030 \\
(0.014)\end{array}$ & $\begin{array}{l}-0.001 \\
(0.015)\end{array}$ & $\begin{array}{l}-0.021 \\
(0.011)\end{array}$ & $\begin{array}{l}-0.046 \\
(0.043)\end{array}$ & $\begin{array}{l}-0.059 \\
(0.030)\end{array}$ \\
\hline $\operatorname{lnc}\left(\beta_{7}\right)$ & $\begin{array}{l}-0.085 \\
(0.028)\end{array}$ & $\begin{array}{l}-0.033 \\
(0.036)\end{array}$ & $\begin{array}{c}0.003 \\
(0.024)\end{array}$ & $\begin{array}{c}0.011 \\
(0.033)\end{array}$ & $\begin{array}{l}-0.053 \\
(0.083)\end{array}$ & $\begin{array}{c}0.069 \\
(0.114)\end{array}$ \\
\hline Has GED & $\begin{array}{c}0.087 \\
(0.015)\end{array}$ & $\begin{array}{c}0.009 \\
(0.016)\end{array}$ & $\begin{array}{c}0.054 \\
(0.014)\end{array}$ & $\begin{array}{c}0.006 \\
(0.018)\end{array}$ & $\begin{array}{c}0.367 \\
(0.058)\end{array}$ & $\begin{array}{c}0.005 \\
(0.058)\end{array}$ \\
\hline Has HS diploma & $\begin{array}{c}0.162 \\
(0.007)\end{array}$ & $\begin{array}{c}0.022 \\
(0.011)\end{array}$ & $\begin{array}{c}0.070 \\
(0.009)\end{array}$ & $\begin{array}{c}0.020 \\
(0.012)\end{array}$ & $\begin{array}{c}0.277 \\
(0.026)\end{array}$ & $\begin{array}{c}0.067 \\
(0.039)\end{array}$ \\
\hline Has associates & $\begin{array}{c}0.230 \\
(0.027)\end{array}$ & $\begin{array}{c}0.013 \\
(0.027)\end{array}$ & $\begin{array}{c}0.152 \\
(0.030)\end{array}$ & $\begin{array}{c}0.074 \\
(0.029)\end{array}$ & $\begin{array}{c}0.447 \\
(0.080)\end{array}$ & $\begin{array}{c}0.081 \\
(0.054)\end{array}$ \\
\hline Has bachelors plus & $\begin{array}{c}0.210 \\
(0.014)\end{array}$ & $\begin{array}{c}0.155 \\
(0.020)\end{array}$ & $\begin{array}{c}0.234 \\
(0.017)\end{array}$ & $\begin{array}{c}0.214 \\
(0.017)\end{array}$ & $\begin{array}{c}0.213 \\
(0.052)\end{array}$ & $\begin{array}{c}0.258 \\
(0.047)\end{array}$ \\
\hline Years attended since 13 & $\begin{array}{c}0.021 \\
(0.011)\end{array}$ & $\begin{array}{c}0.045 \\
(0.024)\end{array}$ & $\begin{array}{c}0.004 \\
(0.010)\end{array}$ & $\begin{array}{c}0.106 \\
(0.017)\end{array}$ & $\begin{array}{c}0.100 \\
(0.029)\end{array}$ & $\begin{array}{c}0.343 \\
(0.032)\end{array}$ \\
\hline Years exp. since 13 & $\begin{array}{l}-0.002 \\
(0.002)\end{array}$ & $\begin{array}{c}0.006 \\
(0.002)\end{array}$ & $\begin{array}{c}0.001 \\
(0.002)\end{array}$ & $\begin{array}{c}0.000 \\
(0.002)\end{array}$ & $\begin{array}{c}0.001 \\
(0.005)\end{array}$ & $\begin{array}{l}-0.002 \\
(0.004)\end{array}$ \\
\hline Age & $\begin{array}{c}0.102 \\
(0.044)\end{array}$ & $\begin{array}{c}0.245 \\
(0.032)\end{array}$ & $\begin{array}{c}0.119 \\
(0.036)\end{array}$ & $\begin{array}{c}0.130 \\
(0.031)\end{array}$ & $\begin{array}{c}1.033 \\
(0.133)\end{array}$ & $\begin{array}{c}1.145 \\
(0.098)\end{array}$ \\
\hline Age squared & $\begin{array}{l}-0.002 \\
(0.001)\end{array}$ & $\begin{array}{l}-0.006 \\
(0.001)\end{array}$ & $\begin{array}{l}-0.002 \\
(0.001)\end{array}$ & $\begin{array}{l}-0.003 \\
(0.001)\end{array}$ & $\begin{array}{l}-0.021 \\
(0.003)\end{array}$ & $\begin{array}{l}-0.028 \\
(0.002)\end{array}$ \\
\hline ASVAB & $\begin{array}{c}0.001 \\
(0.000)\end{array}$ & & $\begin{array}{c}0.001 \\
(0.000)\end{array}$ & & $\begin{array}{l}-0.001 \\
(0.000)\end{array}$ & \\
\hline Missing ASVAB & $\begin{array}{c}0.017 \\
(0.008)\end{array}$ & & $\begin{array}{c}0.049 \\
(0.013)\end{array}$ & & $\begin{array}{l}-0.010 \\
(0.030)\end{array}$ & \\
\hline Black male & $\begin{array}{l}-0.118 \\
(0.014)\end{array}$ & & $\begin{array}{l}-0.066 \\
(0.012)\end{array}$ & & $\begin{array}{l}-0.359 \\
(0.038)\end{array}$ & \\
\hline Hispanic male & $\begin{array}{c}0.032 \\
(0.017)\end{array}$ & & $\begin{array}{l}-0.028 \\
(0.015)\end{array}$ & & $\begin{array}{c}0.028 \\
(0.033)\end{array}$ & \\
\hline Female & $\begin{array}{l}-0.045 \\
(0.009)\end{array}$ & & $\begin{array}{l}-0.103 \\
(0.011)\end{array}$ & & $\begin{array}{l}-0.287 \\
(0.024)\end{array}$ & \\
\hline Unemployment rate & $\begin{array}{l}-0.004 \\
(0.006)\end{array}$ & $\begin{array}{l}-0.004 \\
(0.005)\end{array}$ & $\begin{array}{l}-0.011 \\
(0.006)\end{array}$ & $\begin{array}{l}-0.011 \\
(0.006)\end{array}$ & $\begin{array}{l}-0.021 \\
(0.018)\end{array}$ & $\begin{array}{l}-0.018 \\
(0.015)\end{array}$ \\
\hline Specification & & & & & & \\
\hline Year effects & $\mathrm{x}$ & $\mathrm{x}$ & $\mathrm{x}$ & $\mathrm{x}$ & $\mathrm{x}$ & $\mathrm{x}$ \\
\hline State effects & $x$ & & $\mathrm{x}$ & & $x$ & \\
\hline Individual effects & & $x$ & & $x$ & & $x$ \\
\hline Observations & 36,687 & 36,687 & 30,145 & 30,145 & 27,137 & 27,137 \\
\hline $\mathrm{R}^{2}$ & 0.07 & 0.04 & 0.15 & 0.14 & 0.25 & 0.35 \\
\hline
\end{tabular}

Notes:

- Heteroscedasticity-robust standard errors that are clustered at the state level are in parentheses.

- Sample consists of NLSY97 respondents aged 18-25 years. See Table 2 for a complete description of the sample restrictions.

- Each continuous covariate is centered by its mean from each regression's respective sample.

- Employment-status regressions are linear probability models.

- Full regression results available from the author. 
Table 9: Frequency of panel observations, by whether state of residence will ever adopt the provision of criminal history records over the Internet, before and after policy change, for ex-offenders and non-offenders

\begin{tabular}{|c|c|c|}
\hline Adopting states & Pre-adoption & Post-adoption \\
\hline \multicolumn{3}{|l|}{ Will ever be incarcerated in sample } \\
\hline Not yet incarcerated & 77 & 135 \\
\hline Already incarcerated & 38 & 427 \\
\hline Will never be incarcerated in sample & 1,627 & 11,505 \\
\hline Non-adopting states & Pre-adoption & Post-adoption \\
\hline \multicolumn{3}{|l|}{ Will ever be incarcerated in sample } \\
\hline Not yet incarcerated & 148 & 279 \\
\hline Already incarcerated & 35 & 653 \\
\hline Will never be incarcerated in sample & 2,567 & 19,196 \\
\hline
\end{tabular}

